\title{
ECONOMICS
}

\section{AN INCREASE IN THE RETIREMENT AGE IN CHINA: THE REGIONAL ECONOMIC EFFECTS}

\author{
by
}

Anping Chen

School of Economics

Jinan University, China

and

Nicolaas Groenewold

Business School

University of Western Australia 


\title{
AN INCREASE IN THE RETIREMENT AGE IN CHINA: THE REGIONAL ECONOMIC EFFECTS
}

\author{
Anping Chen, \\ School of Economics, \\ Jinan University, \\ Guangzhou, China, \\ anping.chen@hotmail.com
}

and

Nicolaas Groenewold,*

Economics,

University of Western Australia,

Perth, Australia

nic.groenewold@uwa.edu.au

DISCUSSION PAPER 15.13

*Corresponding author.

This research was partially funded by a National Natural Science Foundation of China Grant (No. 71173092) and the Program for New Century Excellent Talents in University, Ministry of Education of China (No. NCET-12-0681). 


\begin{abstract}
China's pension system is in need of comprehensive reform in that it is fragmented in its coverage and significantly under-funded. Attempts to improve the coverage will likely exacerbate the financial strains. Thus it is urgent to improve the financial sustainability of the system and one policy which has been proposed is to increase the retirement age. There have been similar proposals in many other countries and they are in line with improved health and life-expectancy. In China's case the partial coverage of the system is related to industry structure with much the best coverage being for government and SOE employees. Since this structure differs considerably across the regions in China, it is likely that a change in retirement age will have significantly different effects across China's regions. Inter-regional disparities are already very substantial in China and it will be important to know whether changes in pension arrangements will widen or narrow these disparities. It is the object of the research reported in this paper to throw light on this question.
\end{abstract}

To do this we construct a small theoretical model having some Chinese characteristics. The model has two regions (coast and interior), two sectors (formal and informal) two types of labour (skilled and unskilled), two levels of government (central and regional) and captures some features of the Chinese tax-expenditure system. Pension coverage is limited to skilled workers in the formal sector and pensions are assumed to be paid by regional governments. We linearise the model and solve it numerically using parameter values derived from average Chinese data for the period 2008-2013.

We run two experiments, both involving a shocks designed to mimic an increase in the retirement age from 60 to 61 . The first assumes that the regional governments use the extra net revenue resulting which results from the increase in retirement age for the provision of a government- provided consumption good while in the second case it is assumed that the government uses the revenue to reduce pension premia (or increase pension payments).

In both cases the increase in retirement age increases the supply of skilled workers and depresses the relative skilled wage in both regions but by more in the interior than in the coast. Output of each good increases in each region but formal-sector output increases by more (since only the formal sector uses skilled labour); the income of skilled households falls but that of unskilled households rises; welfare increases in both regions for both household types but by more for unskilled than skilled and by more in the interior than in the coast. In addition, the welfare disparity between the coast and the interior is reduced. The results are similar in sign across the two experiments but the magnitude of the effects is generally larger in the second, i.e., where the regional governments use the additional net revenue to increase pension payments or reduce pension premia rather than simply producing more government output.

Key words: China, pension system, retirement age, regional impacts JEL Classifications: R10, R23, R28, H70, H75 


\section{Introduction}

The financial viability of socially adequate pension schemes is an important policy issue in many countries, developed as well as developing. This reflects both inadequate pension systems inherited from the past as well as a rapidly changing demographic and social environment. Thus in many countries pension reform is urgent, not only to correct existing weaknesses but also to prepare for future developments.

In all these aspects, China is no exception. By the beginning of the 21st century China had inherited a pension system which has been characterised as inadequate in many dimensions - it is fragmented, it is unfair, it is inefficient, it is substantially unfunded, it covers only a fraction of urban workers and almost no rural workers; see, e.g., Zheng (2007), Song (2009), Barr and Diamond (2010), Herd et al. (2010), Alonso et al. (2011), Dorfman et al. (2013), Cai and Cheng (2014) and Wang et al. (2014a,b).

Not only are there serious weaknesses in the pension system inherited from the past, but China faces structural economic changes, demographic pressures and social forces which will require thorough reform of its pension system if it is to provide suitable old-age security for the majority of its citizens. Before the widespread reform of state-owned enterprises (SOEs) in the late 1980 and 1990s which followed the opening-up of China to the rest of the world in the early 1980s, the Chinese pension system was largely urban and firmly based on SOEs which paid for pensions out of their revenue and provided lifetime income security to employees. Rural workers had access to land which was considered to be the basis for the provision of income during old age. But with SOE restructuring, increasing non-SOE employment in the cities and large-scale migration from the country to the cities, the old pension system was seen to be increasingly inadequate to meet even the most basic needs in old age for the majority of Chinese workers. ${ }^{1}$

\footnotetext{
${ }^{1}$ For an interesting analysis of the effects of SOE restructuring on the labour force, see Giles (2009).
} 
Significant reforms implemented in 1991, 1995 and 1997 and subsequent pilot programmes, moved towards greater coverage, improved funding and unification of different components of the existing schemes. By the first decade of the 21st century, however, many commentators such as Barr and Diamond (2010) argued that the weaknesses listed above were still very much present: coverage in rural areas was still low, a large proportion of urban workers outside the formal sector of SOEs, government and large, well-established private firms are not covered, pension liabilities are substantially unfunded - much of the ultimate responsibility for pensions rests with local and provincial governments - and portability is limited.

In addition to the weaknesses of an inherited system, China faces continuing demographic and social change which will have significant impact on the pension system. A major influence on the population age-structure has been the one-child policy (OCP), initially implemented in the early 1980s and of continuing effect, despite recent marginal relaxation of the rules. This has resulted in a reduction of the total fertility rate to significantly less than 2 the effect of which on population dynamics is exacerbated by the OCP-induced imbalance between births of boys and girls. Added to this are continuing improvements in lifeexpectancy. The implications for the support of the elderly can be seen in the dependency ratio (over-60s as a ratio of the working-age population) which is projected to rise from a level of 0.11 in 2010 to about 0.24 in 2030; see Herd et al. (2010).

On the social side, there has been rapid urbanisation fed substantially by internal migration. This has resulted in a rapid increase in the proportion of the rural population which is over 60 with a dependency rate of 0.34 projected for 2030, with some projections suggesting a ratio greater than 0.60 by 2050 if current migration trends continue (Herd et al. 2010). At the same, urbanisation has contributed to an erosion of traditional family support for the aged - the OCP has limited the possibilities of sons' caring for aged parents and inter- 
regional mobility has made this increasingly difficult. The result is that an increasing proportion of the aged population lives alone with little family support (see Herd et al., 2010, Cai and Cheng, 2014, and Alonso et al., 2011).

It is clear, then, that significant reform of China's system for supporting the aged is required and various proposals have been set out; see, e.g., Barr and Diamond (2008, 2010), Herd et al. (2010), Dorfman at al. (2013) and Cai and Cheng (2014). It is not the purpose of this paper to propose alternative reforms or to describe and evaluate in any detail the reforms which have been proposed. Rather, we take one aspect which has featured in many reforms, viz., an increase in the age at which pensions become accessible (the "retirement age") and examine its general economic effects within a multi-regional context. Zhang (2007), Cai (2008), Zeng (2011), Barr and Diamond (2008, 2010) and Dorfman et al. (2013) all discuss proposals regarding increases in the retirement age; of these only Zeng (2011) and Dorfman et al. (2013) analyse possible effects, the first on the pension system itself in the framework of a CGE model and the second on the labour market. Neither adds a regional dimension to their analysis.

We argue that it is important to examine the effects of various proposals not only on the operation of the pension system itself (although that will understandably be the main focus of many studies) but on the economy as a whole since effects of pension reform are likely to extend beyond the pension system itself. Moreover, we argue that, given the likely differential regional impact many policy components will have, it is also important to undertake such economic analysis in a multi-regional context; this is particularly so given the large inter-regional disparities in China and their importance in policy-making at the highest levels and the possibility that pension-reform proposals will exacerbate such disparities. ${ }^{2}$

\footnotetext{
${ }^{2}$ For recent discussion of regional disparities and policies, see Chen and Groenewold (2013, 2014), Lin, Lin and Ho (2013), Rizov and Zhang (2014) and Herrerias and Monford (2015).
} 
We carry out our analysis within the framework of a small theoretical model which has various Chinese features. ${ }^{3}$ The model has two regions (coast and interior), two sectors (formal and informal), two types of labour (skilled and unskilled), two levels of government (central and regional) and captures some features of the Chinese tax-expenditure system. ${ }^{4}$ We assume that skilled workers are employed only by the formal sector and that only skilled workers have pension coverage. This reflects the implications of the references cited above that pension coverage of rural workers and unskilled workers in urban areas and even skilled workers in the urban informal sector is low and that pension coverage is concentrated amongst skilled government, SOE and corporate employees in the formal sector. ${ }^{5}$ In our model pensions are paid by regional governments; while this assumption does not completely reflect current practice, it is the case for government and SOE employees and, besides, many other parts of China’s current pension scheme are still ultimately underwritten by local and provincial governments.

While the model we set up is relatively simple, it is too complicated to solve analytically and we therefore linearise it and solve it numerically using parameter values derived from average Chinese data for the period 2008-2013. ${ }^{6}$ We describe in detail the results of two experiments, both of which involve a shock designed to mimic an increase in the retirement age from 60 to 61 . The two sets of results differ according to the assumption

\footnotetext{
${ }^{3}$ An earlier analysis within the context of an overlapping-generations CGE model is provided by Li and Merette (2005). Unlike our analysis, their focus is on the effects on the pension system as such rather than the economy as a whole; moreover, they don not disaggregate into regions. More recently, Song et al.(2015) also use an overlapping-generations model to analyse the inter-generational welfare effects of various pension reform policies (which do not include a change in the retirement age).

${ }^{4}$ While our structure drastically simplifies the structure of Chinese taxes, we would argue that it captures the salient features; see Zhang and Martinez-Vazquez (2003), Jin et al. (2005), Zhang (2006), Tochkov (2007), Shen et al. (2012), Jia et al. (2014) and Shen and Zou (2015) for information on aspects of the Chinese public finances.

${ }^{5}$ For a similar distinction between informal and formal sectors in a pension context for China see Giles at al. (2011). For a more detailed discussion of the definition of formal and informal sectors with applications to China and India see Rada (2010).

${ }^{6}$ The coastal region consists of Beijing, Tianjin, Hebei, Guangdong, Hainan, Shandong, Fujian, Zhejiang, Jiangsu, Shanghai, Liaoning and Guangxi with the remaining provinces being allocated to the interior region: Shanxi, Inner Mongolia, Jilin, Heilongjiang, Anhui, Jiangxi, Henan, Hubei, Hunan, Sichuan, Chongqing, Guizhou, Yunnan, Shaanxi, Gansu, Qinghai, Ningxia, Tibet, Xinjiang. Papers using this classification include Whalley and Zhang (2007), He et al. (2008), Fleisher et al. (2010) and Su and Jefferson (2012).
} 
made about closure: in the first it is assumed that the regional governments use the extra net revenue resulting from the increase in retirement age for the provision of a governmentprovided consumption good while in the second case it is assumed that the government uses the revenue to reduce pension premia (or increase pension payments).

In the case where the regional governments spend the additional net revenue on increasing government output, we find that the increase in retirement age increases the supply of skilled workers and depresses the relative skilled wage in both regions but by more in the interior than in the coast. Output of each good increases in each region but formal-sector output increases by more (since only the formal sector uses skilled labour) and about the same in the two regions. With the change in the relative wage favouring unskilled labour, the income of skilled households falls but that of unskilled households rises. Welfare increases in both regions for both household types but by more for unskilled than skilled and by more in the interior than in the coast. In addition, the welfare disparity between the coast and the interior is reduced.

If the regional governments use the additional net revenue to reduce pension premia or to increase pension payments, the results are generally substantially different. The increase in retirement age allows either a fall in pension premia of about $25 \%$ or a rise in pension payments of about 30-35\%. The rise in the skilled labour supply is the same as in the previous simulation but, because most of it now needs to be absorbed in the private sector (rather than in government production), the relative wage for skilled workers falls by more. Flow-on effects to the rest of the economy are also generally greater, often by a factor of two to three. Welfare again rises for both household types in both regions, in all cases by more than in the previous case. The inter-regional welfare disparity is also reduced by this policy. Thus this policy has beneficial effects on the pension system (it allows the pension to be increased or pension premia to be reduced) and has beneficial effects on the rest of the 
economy, including output increases, welfare improvements and a reduction in the interregional welfare disparity.

The remainder of the paper is structured as follows. In the next section we set out the model and also briefly discuss its linearisation and calibration. Section 3 is devoted to a specification of the simulations we carry out and section 4 contains a discussion of the results of these simulations. Conclusions are presented in section 5.

\section{Model}

The model has two regions, conventionally labelled interior and coast $(i=I, C)$; two private sectors, formal and informal $(j=F, N)$, each of which produces a homogeneous output; two types of households, skilled and unskilled $(k=U, S)$; and two levels of government - a regional government in each of the two regions and a central government. ${ }^{7}$ We discuss each of these aspects of the model in turn, starting with the household sector.

Households. Households derive utility from the consumption of the two privately-produced goods as well as from a good supplied "free of charge" by governments. There are two types of households (skilled and unskilled) in each region. We assume a representative household of each type in each region with potentially different preferences modelled by a constantelasticity-of-substitution (CES) utility function of the form: ${ }^{8}$

$$
V_{k i}=\beta_{k i}\left(\gamma_{N k i} C_{N k i}^{-\rho_{k i}}+\gamma_{F k i} C_{F k i}^{-\rho_{k i}}+\gamma_{G k i} G H_{i}^{-\rho_{k i}}\right)^{\frac{-1}{\rho_{k i}}}, \quad i=I, C, \quad k=U, S,
$$

where $V_{k i}=\quad$ utility of the representative household of type $k$, region $i$,

$$
\begin{aligned}
C_{N k i}=\quad \text { real private consumption of the informal-sector good per household of } \\
\text { type } k \text {, region } i \text {, }
\end{aligned}
$$

\footnotetext{
${ }^{7}$ We use "private" in relation to the production sectors to mean non-general government and include SOEs and other government-owned producers in these sectors.

${ }^{8}$ We include a list of variable definitions in Appendix 1.
} 


$$
\begin{aligned}
& C_{F k i}=\quad \text { real private consumption of the formal-sector good per household of } \\
& \text { type } k \text {, region } i, \\
& G_{i}=\quad \text { real government-provided consumption good per household, region } i, \\
& \beta_{k i}=\quad \text { the scale parameter for household of type } k \text {, region } i, \\
& \gamma_{j k i}=\quad \text { the share parameters, good } j \text {, household type } k \text {, region } i, \\
& \rho_{k i}=\quad \text { the substitution elasticity parameter, household type } k \text {, region } i \text { (the } \\
& \left.\quad \text { elasticity of substitution is } 1 /\left(1+\rho_{k i}\right)\right),
\end{aligned}
$$

with:

$$
\begin{aligned}
& \beta_{k i}>0, \quad k=U, S, \quad i=I, C, \\
& 0<\gamma_{j k i}<1, \quad j=N, F, G, \quad k=U, S, \quad i=I, C, \\
& \gamma_{N k i}+\gamma_{F k i}+\gamma_{G k i}=1, \quad k=U, S, \quad i=I, C, \quad \text { and } \\
& \rho_{k i}>-1, \quad k=U, S, \quad i=I, C .
\end{aligned}
$$

Households maximise utility subject to a budget constraint. To formulate the household budget constraint we need to combine quantities of the two goods and we use unskilled labour as the numeraire, throughout. We introduce a value-added tax (VAT) into the model. Since there are no intermediate goods in the model, the VAT is equivalent to a tax on the value of final output, all of which is consumed and, since households are assumed to spend all their income, the VAT is also equivalent to an income tax. We therefore model households as "paying" the VAT which the central government collects at a given rate $T_{V}$ so that the household budget constraint for household $k$ in region $i$ can be written as: $P_{N} C_{N k i}+P_{F} C_{F k i}=J_{k i}\left(1-T_{V}\right), \quad k=U, S, \quad i=I, C$, where $P_{N}$ and $P_{F}$ are the prices of goods $N$ and $F$ in terms of unskilled labour and $J_{k i}$ is household income in terms of unskilled labour for household type $k$, region $i$. 
Utility maximisation subject to the household budget constraint gives the demand functions: ${ }^{9}$

$$
\begin{aligned}
& C_{N k i}=\frac{J_{k i}\left(1-T_{v}\right)}{P_{N}+P_{F}\left(\frac{P_{N}}{P_{F}} \frac{\gamma_{F k i}}{\gamma_{N k i}}\right)^{\frac{1}{1+\rho_{k i}}}}, \quad k=U, S, \quad i=I, C, \\
& C_{F k i}=\frac{J_{k i}\left(1-T_{v}\right)}{P_{F}+P_{N}\left(\frac{P_{F}}{P_{N}} \frac{\gamma_{N k i}}{\gamma_{F k i}}\right)^{\frac{1}{\rho_{k i}+1}}}, \quad k=U, S, \quad i=I, C .
\end{aligned}
$$

Households receive income from wages, profits and pensions. Firms in the formal sector distribute profits to skilled households in their own region while firms in the informal sector distribute profits to unskilled households in their own region. Firms distribute profits in equal-per-capita amounts to all households in the region in which they are located.

To reflect the partial pension coverage in China, as described in section 1, we assume that only skilled labour is covered by a pension plan and therefore retired skilled workers in region $i$ receive a pension, $W_{R i}$, and employed skilled workers pay a pension premium, $R_{i}$, to the government. It is assumed that in region $i$ a fixed proportion, $r_{i}$, of skilled workers have retired, this proportion being the outcome of government policy and the population age structure, both of which we assume to be exogenous. Unskilled households do not retire, do not receive a pension and are not required to pay a pension premium. The income for the representative unskilled household can therefore be written as:

$J_{U i}=1+\Pi H_{N i}, \quad i=I, C$,

where the first term on the right-hand side is the wage (the unskilled wage is numeraire) and $\Pi H_{N i}$ denotes the representative unskilled household's share of profits from the informal sector. Employed skilled households receive a wage, $W_{S i}$, an equal share of formal-sector profits, $\Pi H_{F i}$, retired skilled workers receive a pension and all employed skilled workers pay

\footnotetext{
${ }^{9}$ Note that there is no $i$ subscript on $P_{N}$ or $P_{F}$. This reflects the assumption, to be made explicitly below, that both goods are freely traded between regions so that, in the absence of transportation costs, there will be a single price, nationwide.
} 
a pension premium. We can therefore write income for the representative skilled household as:

$J_{S i}=\left(1-r_{i}\right)\left(W_{S i}-R_{i}\right)+r_{i} W_{R i}+\Pi H_{F i}, \quad i=I, C$.

Households may migrate between sectors and between regions. In China, interregional migration has traditionally been subject to restrictions based on the household registration system, or hukou, which we model as imposing a cost on migration. ${ }^{10}$ We model the system as one in which no restrictions are imposed on inter-sectoral migration or on interregional migration by unskilled labour but costly restrictions are imposed on the interregional migration of skilled households. There is no inter-sectoral migration by skilled workers since they are employed only in the formal sector. Therefore there is a single, nationwide unskilled wage but the skilled wage is equalised subject to migration costs. In particular, skilled workers are assumed to be able to migrate between one region and the other only in the long run and subject to hukou costs. In the short run regional skilled labour supplies are assumed exogenous. To simplify the migration equilibrium condition, we assume that inter-regional migration flows are dominated by those from the poor to the rich region. This assumption avoids the discontinuities which result from two-way costly migration; see Woodland and Yashida (2006) for an approach similar to ours but applied to immigration from poor to rich countries. Thus in long-run equilibrium the skilled wage in the coast (the richer region) will exceed the skilled wage in the interior by the hukou cost which we assume to be proportional to the wage:

$$
W_{S C}=W_{S I}(1+\mu) \text {, }
$$

where $\mu$ is the hukou cost parameter.

\footnotetext{
${ }^{10}$ See Cheng and Selden (1994) for a general description and history of the hukou system. and Bao et al. (2011) for a more recent discussion and modelling considerations.
} 
Firms. We assume that the number of firms in each sector (formal and informal) and in each region is fixed and, without loss of generality, we set this number equal to 1 in each case.

The firm in the informal sector produces output using land (in fixed supply), unskilled labour and a public infrastructure good provided by the regional government. The firm in the formal sector uses both skilled and unskilled labour as well as capital (in fixed supply) and an infrastructure good provided by the government in its region. ${ }^{11}$ Both sectors use CobbDouglas constant-returns-to-scale production technology:

$$
\begin{gathered}
Y_{N i}=B_{N i}(L A N D)^{\left(1-\alpha_{N U i}-\alpha_{N G i}\right)}\left(L_{N U i}\right)^{\alpha_{N U i}}\left(G R F_{N i}\right)^{\alpha_{N G i}}, \quad 0<\alpha_{N U i}, \alpha_{N G i},\left(1-\alpha_{N U i}-\alpha_{N G i}\right)<1, \\
Y_{F i}=B_{F i}(C A P I T A L)^{\left(1-\alpha_{F U i}-\alpha_{F S i}-\alpha_{F G i}\right)} L_{F U i}^{\alpha_{F U i}} L_{F S i}^{\alpha_{F S i}}\left(G R F_{F i}\right)^{\alpha_{F G i}}, \\
0<\alpha_{F U i}, \alpha_{F S i}, \alpha_{F G i},\left(1-\alpha_{F U i}-\alpha_{F S i}-\alpha_{F G i}\right)<1,
\end{gathered}
$$

where $B_{N i}$ is total factor productivity (TFP), $L_{N U i}$ is total (unskilled) employment in the informal sector and $G R F_{N i}$ represents regional government expenditure on infrastructure which benefits firms in the informal sector, all in region $i$. Similarly, $B_{F i}$ is TFP in the formal sector, $L_{F U i}$ and $L_{F S i}$ are employment of unskilled and skilled workers in this sector and $G R F_{F i}$ is infrastructure provided by region $i$ 's government to firms in the formal sector in the region. Since we assume both land and capital to be immobile factors in fixed supply, we can simplify and write:

$$
D_{N i}=B_{N i}(L A N D)^{\left(1-\alpha_{N U i}-\alpha_{N G i}\right)} \text {, }
$$

and

$$
D_{\mathrm{Fi}}=B_{F i}(C A P I T A L)^{\left(1-\alpha_{F U i}-\alpha_{F S i}-\alpha_{F G i}\right)},
$$

so that the production functions can be written as:

$$
Y_{N i}=D_{N i} \alpha_{N U i}^{\alpha_{N U i}}\left(G R F_{N i}\right)^{\alpha_{N G i}}, \quad 0<\alpha_{N U i}, \alpha_{N G i},\left(1-\alpha_{N U i}-\alpha_{N G i}\right)<1, \quad i=I, C \text {, and }
$$

\footnotetext{
${ }^{11}$ It is clearly more plausible to assume inter-regional immobility of land than immobility of capital. Nevertheless, it is possible to argue that capital moves more slowly than labour and to restrict our analysis to the length of time in which labour, but not capital, can move. Besides, experimentation with an earlier version of this model suggests that introducing capital mobility considerably complicates the interpretation of results of many shocks without changing their overall thrust.
} 


$$
\begin{gathered}
Y_{F i}=D_{F i} L_{F S i}^{\alpha_{F S i}} L_{F U i}^{\alpha_{F U i}}\left(G R F_{F i}\right)^{\alpha_{F G i},} \quad 0<\alpha_{F S i}, \alpha_{F U i}, \alpha_{F G i},\left(1-\alpha_{F S i}-\alpha_{F U i}-\alpha_{F G i}\right)<1 \\
i=I, C .
\end{gathered}
$$

Consider now firms’ behaviour. Profits (in terms of units of unskilled labour) are defined as:

$$
\begin{array}{ll}
\Pi_{N i}=\left(1-T_{N i}\right) P_{N} Y_{N i}-L_{N u i}, & i=I, C, \\
\Pi_{F i}=\left(1-T_{F i}\right) P_{F} Y_{F i}-L_{F U i}-W_{S i} L_{F S i}, & i=I, C,
\end{array}
$$

where $T_{N i}$ is the tax on informal-sector output and $T_{F i}$ is the tax levied on the value of output of the formal sector and $W_{S i}$ is the skilled wage relative to the unskilled wage, all in region $i$. We assume that each firm takes the wage, the tax rate and the quantity of infrastructure as given. Hence the only choice variable in each case is the level of employment - unskilled in the informal sector and both skilled and unskilled in the formal sector - and this choice will also determine output via the production function. We follow convention and assume that firms in both sectors choose employment to maximise profits. The profit-maximising conditions will result in the usual marginal productivity conditions. For the formal sector

$$
\begin{array}{ll}
\alpha_{F S i}\left(1-T_{F i}\right) P_{F} Y_{F i}=W_{S i} L_{F S i}, & i=I, C, \\
\alpha_{F U i}\left(1-T_{F i}\right) P_{F} Y_{F i}=L_{F U i}, & i=I, C,
\end{array}
$$

and for the informal sector:

$$
\alpha_{N U i}\left(1-T_{N i}\right) P_{N} Y_{N i}=L_{N U i}, \quad i=I, C
$$

On the labour supply side, each unskilled household provides one unit of labour inelastically and each skilled household provides $\left(1-r_{i}\right)$ units of labour inelastically. Hence population, labour force, labour supply, employment and the number of households are all equal for the unskilled population but for the skilled there is a distinction between population and households (which are equal), on the one hand, and employment and labour force (which are equal), on the other. We use $Q_{U}, Q_{S}$ and $Q$ to denote the number of unskilled, skilled and total households respectively. 
Governments. There are two levels of government in the model: central and regional. Following our description of the pension system in China in Section 1, we assume that, while the central government determines the parameters of the pension system, pensions are administered at the regional level by provincial and local governments. In addition, given the evidence that in many cases local and provincial governments are financially responsible, as a last resort, for pension payments, we simplify the structure of the model and assume that pension premium income and pension payments are part of the regional governments' budgets.

The central government levies a VAT at a uniform rate across the country and shares the revenue with the regional governments, returning a share $(1-\theta)$ of the revenue raised in each region. The central government uses its tax revenue to provide a government consumption good to the residents of each region in amounts which are the same per capita in each region but may differ across the regions. It produces this good using only skilled labour which it hires in the market in the region in which the good is provided. Production technology is linear:

$Q_{i} G C_{i}=L_{G C S i}, \quad i=I, C$,

where $L_{G C S i}$ is the amount of skilled labour hired by the central government in region $i$ and $Q_{i}$ is population of region $i$. The government budget constraint in terms of units of unskilled labour is:

$Q_{I} P_{G C I} G C_{I}+Q_{C} P_{G C C} G C_{C}=\theta T_{V}\left[\left(Q_{S I} J_{S I}+Q_{U I} J_{U I}\right)+\left(Q_{S C} J_{S C}+Q_{U C} J_{U C}\right)\right]$

where $P_{G C i}$ is the price of central government output in region $i, Q_{S i}$ is the population of skilled worker households in region $i$ and $Q_{U i}$ is the population of unskilled worker households in region $i$.

Regional governments levy a tax on the productive activities of both sectors in their region at rates $T_{N}$ and $T_{F}$. They also receive a share, $(1-\theta)$, of the VAT levied by the central 
government as well as pension premium income from skilled workers in the formal sector in their region. Each regional government provides a consumption good to households within its region in equal per capita amounts, as well as providing infrastructure to firms in both sectors. Regional governments also pay pensions to retired skilled workers. The regional governments' budget constraints therefore have the form:

$$
\begin{aligned}
Q_{i} P_{G R i} G R H_{i}+P_{G R i}\left(G R F_{N i}+\right. & \left.G R F_{F i}\right)+r_{i} Q_{S i} W_{R i}=(1-\theta) T_{V}\left(Q_{S i} J_{S i}+Q_{U i} J_{U i}\right)+T_{N i} P_{N} Y_{N i} \\
& +T_{F i} P_{F} Y_{F i}+\left(1-r_{i}\right) Q_{S i} R_{i}, \quad i=I, C,
\end{aligned}
$$

where $P_{G R i}$ is the price of the regional government's output in region $i, G R H_{i}$ is the amount per capita of the government good provided by region i's government to households in its region and $G R F_{j i}$ is the amount of the infrastructure good (non-rival in use) provided to the firms in sector $j$, region $i$. The components on the right-hand side of (10) are the regional government's share of the VAT, tax revenue from the output tax on the two sectors and income from the pension premium paid by skilled workers in its region.

It is assumed that regional governments have the same production technology as the central government and produce an identical good which can be provided either as a consumption good to households or to firms as infrastructure. Thus

$$
Q_{i} G R H_{i}+G R F_{N i}+G R F_{F i}=L_{G R S i}, \quad i=I, C,
$$

where $L_{G R S i}$ is the amount of skilled labour employed by the regional government in region $i$.

The simple government production function implies that the relative price of the government good in region $i, P_{G C i}$, and $P_{G R i}$, is simply the real wage of skilled labour in region $i, W_{S i}$ :

$P_{G C i}=P_{G R i}=W_{S i}, \quad i=I, C$.

Closure and definitions. It remains to define a number of important aggregate variables and set out market-clearing conditions to complete the specification of the model. 
First, the aggregate counterparts of a number of regional variables are defined. We begin with output and define both regional output and national output which are given, in terms of units of unskilled labour, by:

$Y_{i}=P_{N} Y_{N i}+P_{F} Y_{F i}, \quad i=I, C$,

$Y=Y_{I}+Y_{C}$

Similarly for income (per capita) at the regional and national levels. Since income is already defined in terms of units of unskilled labour we just weight regional per capita incomes by populations and add:

$J_{i}=\left(Q_{U i} / Q_{i}\right) J_{U i}+\left(Q_{S i} / Q_{i}\right) J_{S i}, \quad i=I, C$,

$J=\left(Q_{I} / Q\right) J_{I}+\left(Q_{C} / Q\right) J_{C}$.

The appropriate procedure for welfare is less straightforward because of the problem of interpersonal comparison of utilities. We decide to treat all individuals equally and simply measure regional and national welfare as the population-weighted average of the utilities of the different households in each case:

$$
\begin{aligned}
& V_{i}=\left(Q_{U i} / Q_{i}\right) V_{U i}+\left(Q_{S i} / Q_{i}\right) V_{S i}, \quad i=I, C, \\
& V=\left(Q_{I} / Q\right) V_{I}+\left(Q_{C} / Q\right) V_{C} .
\end{aligned}
$$

Next, we introduce a number of definitions and market clearing conditions.

$G H_{i}$, the amount of the government good per capita received by households in region $i$ from both sources (regional and national governments), is the sum of its components since both levels of government produce an identical good. Hence it is given by:

$G H_{i}=G R H_{i}+G C_{i}, \quad i=I, C$.

Market-clearing conditions are imposed on goods and labour markets. It is assumed that the output of each sector is homogeneous across regions and trades freely between regions making market-clearing a national condition. All private production is consumed so 
that goods-markets clearing in each sector implies that national output is equal to national consumption:

$Y_{N I}+Y_{N C}=Q_{U I} C_{N U I}+Q_{S I} C_{N S I}+Q_{U C} C_{N U C}+Q_{S C} C_{N S C}$

and

$Y_{F I}+Y_{F C}=Q_{U I} C_{F U I}+Q_{S I} C_{F S I}+Q_{U C} C_{F U C}+Q_{S C} C_{F S C}$

Market-clearing is also imposed on the labour markets:

$$
\begin{array}{ll}
L_{N U i}+L_{F U i}=L_{U i,} & i=I, C, \\
L_{F S i}+L_{G C S i}+L_{G R S i}=L_{S i} . & i=I, C,
\end{array}
$$

where $L_{S i}$ and $L_{U i}$ are employment of skilled and unskilled workers respectively, in region $i$.

The relationship between labour supply and population is straightforward. The number of unskilled households equals the unskilled labour force and the number of skilled households equals the skilled labour force plus retired skilled workers:

$$
\begin{array}{ll}
L_{U i}=Q_{U i}, & i=I, C, \\
L_{S i}=\left(1-r_{i}\right) Q_{S i}, & i=I, C .
\end{array}
$$

Regional and national populations are defined as:

$$
\begin{aligned}
& Q_{U}=Q_{U I}+Q_{U C}, \\
& Q_{S}=Q_{S I}+Q_{S C}, \\
& Q_{i}=Q_{U i}+Q_{S i}, \quad i=I, C, \\
& Q=Q_{S}+Q_{U} .
\end{aligned}
$$

Firms are assumed to distribute all their profits to households in their own region in equal per capita amounts.

$$
\begin{array}{ll}
\Pi_{N i}=Q_{U i} \Pi H_{N i}, & i=I, C, \\
\Pi_{F i}=Q_{S i} \Pi H_{F i}, & i=I, C .
\end{array}
$$

This completes the specification of the model. To summarise, the short-run version of the model consists of 71 equations, (1) to (20) in 70 endogenous variables: $V_{k i}, C_{j k i}, G H_{i}, P_{j}$, 
$J_{k i}, \Pi H_{k i}, Y_{j i}, L_{j U i}, L_{F S i}, \Pi_{j i}, W_{S i}$, one $G C_{i}, G R H_{i}, Q_{i}, L_{G C S i}, L_{G R S i}, P_{G C i}, P_{G R i}, Y, Y_{i}, J, J_{i}, V, V_{i}$, $L_{U i}, L_{S i}, Q_{U i}, Q_{S}, Q$. One of the equations is redundant, however, since the household and government budget constraints, definitions and one of the product-market clearing conditions imply the other; we drop one of the product-market clearing conditions in the simulations which follow.

Short-run and long-run versions of the model. The model set out above is the short-run version of the model. It is defined by the assumption that skilled labour is not interregionally mobile which is reflected by the fact that the regional populations of skilled households are exogenous. We relax this assumption in the long run by making these populations endogenous (although subject to an exogenous national population of skilled households) and by adding the migration equilibrium equation (4). In this approach to the short-run/long-run distinction we follow Krugman (1991) and define the short run as the length of time before inter-regional migration begins to respond to the changes in the wage differential. The distinction is based on the idea that migration is slow to respond fully to changes in economic incentives. Thus, for example, Pissarides and McMaster (1990) estimate that it takes as long as 20 years for reasonably complete adjustment of migration to labour-market shocks.

Linearising and calibrating the model. The model as it stands is too complicated to solve analytically so that we linearise it in terms of proportional changes for which we use a process of log differentiation. This converts the model from one which is non-linear in the levels to one which is linear in the proportional rates of change of the variables. The resulting linearised versions of equations (1)-(20) are given in Appendix 2. 
Having linearised the model in terms of proportional changes, we can solve the model for any one of the (changes in the) endogenous variables in terms of (the changes in) the exogenous variables. However, given the number of endogenous variables, this is unlikely to lead to any interpretable results and we proceed to solve the model numerically, using data for China's regions (reported in Table 1) to calibrate the key parameters of the model, detailed discussion of which we relegate to Appendix 3.

[Table 1 about here]

\section{Simulations}

In the next section we report the results of two simulations. Both reflect the effects of an increase in the retirement age but differ in the way in which the model is closed; in particular, we make two alternative assumptions about the variables which are assumed endogenous to satisfy the regional government budget constraints.

The shock is to the proportion of the skilled population which is retired, $r_{i}$. The size of the shock is chosen so as to mimic the effect of an increase in retirement age from 60 to 61. While at this level, the shock is assumed to be the same for each region, the actual proportional change in $r_{i}$ differs across regions because $r_{i}$ itself, life expectancy and, so, the proportion of retirees who are 60 all differ across the regions. The effect of all these is that the proportional shock to $r_{i}$ is -0.1170 for the coast and -0.1481 for the interior region. The reason for the larger shock to the interior region is that it has a higher proportion of the skilled population retired but a lower life-expectancy so that, in the interior, 60-year-olds form a greater proportion of the retired skilled population. ${ }^{12}$

\footnotetext{
${ }^{12}$ Details of the computation of shock sizes are provided in Appendix 3.
} 
The two simulations we report differ according to the closure assumptions made for the regional government budget constraints. In the first, they are assumed to let the level of the government-provided consumption good vary to ensure a balanced budget and in the second they allow the pension premium to adjust. In both cases the central government allows its provision of the consumption to vary (with the restriction that the proportional changes are the same in the two regions) to ensure budget balance. We focus on the alternative for the regional government since the change in retirement age affects its budget directly but affects the central government only indirectly.

\section{Results}

In this section we report the results of two simulations of the model, the first (Simulation 1) based on the assumption of endogenous $G R H_{i}$ and the second (Simulation 2) assuming that $R_{i}$ is endogenous.

\subsection{Simulation 1: $G R H_{i}$ endogenous in the regional governments' budget constraints}

The shock is a fall in $r_{i}$, which, as explained above, is set to -0.1170 and -0.1481 for the coast and interior respectively. These are proportional changes in $r_{i}$ and the results are multiplied by 100 so that they may be interpreted as percentages. Selected results are reported in Table 2 with the full set reported in Appendix 4.

[Table 2 about here]

Closure assumptions for the government budget constraints are as follows: for the central government $G C_{i}$ adjusts to ensure the constraint is satisfied (assuming equiproportionate increases in each region) and for the regional government $G R H_{i}$ adjusts for each region to satisfy the constraint. We begin with the short-run effects and consider each market in turn. 
Labour supply, employment and wages. The "initial" effects of the increase in the retirement age are on the supply of skilled labour which increases by $5.06 \%$ nationally, with both regions' labour supply going up: by $6.26 \%$ and $3.72 \%$ for the interior and the coast respectively. The larger effect for the interior reflects both the larger shock and the fact that a higher proportion of the skilled labour force is retired. ${ }^{13}$

Since labour markets clear, the increase in skilled labour supply must be employed either by the formal sector or by government or both. The increases in employment by the private firms are of a similar order of magnitude across the regions, although larger for the interior than for the coast (2.38\% and $2.11 \%$ respectively) reflecting the different shock sizes. The change in employment of skilled labour by the central government is of a similar order of magnitude: just under $2.5 \%$ in each region. Note that this occurs despite the fact that there is no direct effect of the shock on the central government; moreover the only central government revenue is from the VAT calculated on incomes and incomes in both regions fall. Hence the retirement shock results in a tightening of its budget constraint but, nevertheless, it is able to employ more labour since the price of skilled labour falls, driven by the increase in its supply.

The proportional increases in the employment of skilled labour by the regional governments are $18.71 \%$ and $9.08 \%$ for the interior and the coast respectively. Two features of these number stand out: they are much larger than the employment effects for the central government and for the private sector and the effect in the interior is more than twice as large as in the coast. Given the simple production function assumed for government, employment changes predominantly reflect changes in government supply of the government good. Supply changes, in turn, are driven mainly through the government budget constraint by a substantial change in the cost of production ( which equals the skilled wage). The fall in the

\footnotetext{
${ }^{13}$ From the linearised equation for the supply of skilled labour, (19') and the assumption that in the short run the skilled population is exogenous in each region, a unit fall in $r_{i}$ in each region implies that $l_{S i}$ is equal to $r_{i} /\left(1-r_{i}\right)$ which is increasing in $r_{i}$.
} 
skilled wage makes it possible to produce more output with no change in government revenue. This ability is more marked for the regional governments than it is for the central government since regional governments produce two types of goods, the cost of both of which falls with the skilled wage whereas the central government produces only the consumption good. Our current closure assumptions imply that both levels of government use these cost savings to expand the provision of the government consumption good. The greater regional government effect is reinforced by the fact that only for the regional governments is there a direct budgetary impact of the increase in retirement age - this both reduces the pension payments made by the government and increases pension premium income from the additional skilled workers.

The second feature of the government employment effects is that it is much larger in the interior than it is in the coast. This reflects the difference in size of the initial shocks as explained previously so that the mechanism discussed above is stronger in the interior than it is in the coast.

Since skilled labour supply increases and unskilled does not, it is not surprising that the relative wage for skilled labour falls and that it does so by more in the interior where the employment effect is larger.

Prices and output. The price of formal-sector output falls while the price of informal-sector output rises, with the change in formal-sector price being considerably larger. The fall in formal-sector price reflects the reduction in the wage for skilled labour which is used only in the formal sector. The skilled wage cut leads firms to increase their demand for skilled labour and increase their output supply which, in turn, requires a fall in output price to maintain product-market clearing. The skilled wage reduction also causes formal-sector firms to substitute skilled labour for unskilled labour with the released unskilled labour 
migrating to the informal sector which, in turn, is able to increase its output. This is consistent only with a rise in the price of its output. Thus, output in each of the two sectors in each region increases.

While the changes in output of the informal sectors is small in both regions, it is larger in the interior, reflecting unskilled labour released by the formal sector as well as a small amount of migration of unskilled workers from the coast to the interior.

Incomes and consumption. Income for unskilled households rises in both regions but falls in both regions for the skilled households. The rise in unskilled income reflects increasing informal-sector profits. The rise in the income of unskilled households is small in both regions but larger in the coast, reflecting a larger profit rise in that region. The influences on skilled income are more complicated. First, the fall in the retirement proportion increases wage income net of pension payments and premia; second, wage income falls significantly and, third, formal sector profits also fall. The fall in skilled household incomes is roughly equivalent in both regions which reflects the larger wage fall in the interior but a larger profit fall in the coast.

Why do profits change? For the formal sector, the wage bill falls (the skilled wage falls by more than the increase in skilled employment and unskilled employment falls) and output increases. But these two positive effects are more than offset by the fall in the relative price of formal sector output, resulting in an overall fall in profits. This feeds through into profit distribution to skilled households and therefore to their incomes. For informal firms, output increases and the relative price rises, both increasing revenue. The wage bill also increase due to higher employment (at a given wage) but they do so by less than the value of output so that profits rise, by a small amount in each case, although by more in the interior 
than in the coast. Again, the effects feed through to unskilled households who are the recipients of profit distributions from the informal sector.

Consumption of both goods rises for unskilled households in both regions, reflecting the increase in incomes in both regions. The relative regional magnitude is the same for each of the goods and reflects that of incomes, with a larger rise in the coast. Consumption of the formal good goods rises more than that of informal goods reflecting a relative price change in favour of formal goods. Consumption changes for skilled households are smaller than for unskilled households and signs are mixed. Their consumption of formal goods rises in both regions while consumption of informal goods falls in both regions. This reflects the combined effects of income falls for skilled households and relative price movements against the informal-sector good.

Welfare. Welfare depends on both private consumption and consumption of the government good. Consider government consumption, $G H$, first. $G H$ increases by a large proportion in both regions but more in the interior than in the coast: 14.47 and 10.72 in the interior and the coast respectively. Since central government expenditure is constrained to increase in the same proportion in the two regions (and is small), the regional difference in the change in $G H$ largely reflects changes in the consumption good provided by the regional governments, $G R H$, which are 33.23 and 16.52 in the interior and the coast respectively. This clearly reflects the greater increase in skilled labour, used in the production of the government good, in the interior and the consequent greater fall in the relative skilled wage in that region.

Turning to the effects of these changes on welfare, we see that welfare goes up for each type of household in both regions but it goes up by more for unskilled households than for skilled households and by more in the interior for both household types. The difference between skilled and unskilled household welfare is not surprising since the increases in 
consumption are bigger for the unskilled households and all households receive the same increase in government consumption. The different regional effects reflect a balance between the influences of private and public consumption. For unskilled households, private consumption of both goods increases more in the coast than in the interior but the effect of this is more than offset by the larger increase in government consumption in the interior, so that the overall welfare increase is greater in the interior. For the skilled households the effects of private and public consumption on welfare both work in the same direction - both types of consumption increase by more (or fall by less) in the interior, making for an unambiguously greater increase in welfare for the skilled households in the interior than for their coastal counterparts.

Regional Disparities. An important question to consider when analysing the regional effects of aggregate shocks, is whether they exacerbate or ameliorate existing inter-regional disparities. Disparities can be measured in a number of ways and we use three measures: per capita output, per capita income and welfare. We have chosen our two regions so that the coastal region is more prosperous than the interior and this is in fact the case for our data set - both per capita output and income is higher in the coast. We presume that this carries over into welfare so that an policy change which favours the interior over the coast will be one which reduces disparities and vice versa. Table 2 shows that output per capita and income per capita have mixed results. Output per capita of informal-sector output rises by more in the interior but formal-sector output rises by more in the coast. Similarly, per capita income of unskilled households rises by more in the coast but that of skilled households falls by less in the interior. The welfare measure shows an unambiguous result: it rises by more in the interior for both types of households. The contrast between the implications for the welfare measure of disparities and the more common income and output measures is due largely to 
the fact that the latter two omit the effects of changes in government expenditure which, as we saw above, greatly favour the interior.

To summarise the short-run effects. The increase in retirement age "initially” increases skilled labour supply and employment, by more in the interior than in the coast. This reduces the skilled wage, by more in the interior than in the coast. Output of each good increases in each region but formal-sector output increases by more and about the same in the two regions. The price of the informal sector's output goes up and the price of the formal sector's output goes down. With the change in the relative wage favouring unskilled labour, the income of skilled households falls but that of unskilled households rises. Welfare increases in both regions for both household types but by more for unskilled than skilled and by more in the interior than in the coast. Generally the differences between the household types are greater than between regions. It would seem to be a good policy, therefore, since all groups gain in welfare terms. In addition, the welfare disparity is reduced. But the analysis ignores the disutility of working longer for those who would otherwise retire (or the utility of retirement for those who have to work an extra year).

Long run. The distinction between short and long runs is that in the long run skilled households can migrate and they do this in response to wage differentials across the regions. Skilled wages fall in both regions in the short run but the fall is larger in the interior so that we expect migration of skilled workers from the interior to the coast, which in fact happens. This is slightly offset by a reversal of the short-run migration of unskilled workers from the coast to the interior. Skilled households in the coast now suffer a greater drop in income than they did in the short run but the reverse is true for interior skilled workers whose income fall is moderated by the migration flow. This greater fall in coastal skilled incomes, leads to a 
substantial worsening of their welfare although it is still better than in the initial situation. Inter-regional welfare disparities are therefore further narrowed as are disparities in per capita output and household income. In general, migration narrows the inter-regional gaps between corresponding variables compared to the short run.

\subsection{Simulation 2: $R_{i}$ endogenous in the regional governments' budget constraints}

The increase in the retirement age increases net revenue for the regional governments since they pay fewer pensions and receive more pension premium income. In the current closure, this additional revenue plus the benefits from lower government production costs are used to reduce the premium level in contrast to the previous case where it was used to increase the provision of the government consumption good. It can be seen from the second set of simulation results in Table 2 that the consequent fall in $R$ is about $25 \%$ with the fall being larger in the interior. This reduction in the premium which skilled workers have to pay the regional government has powerful flow-on effects through the rest of the economy where we see that, by and large, the changes in endogenous variables are about two to three times the magnitudes of those in the previous simulation.

Labour supply, employment and wages. The increase in labour supply is what it was for simulation 1 , both overall and by region. The increase in private employment of skilled labour is now much greater and the cause is not hard to find - now that government production is not the endogenous variable for the regional governments, they do not employ more labour for this as they did in the previous case. This leaves more skilled labour to be absorbed by the private sector which increases by $8.44 \%$ in the interior and $4.58 \%$ in the coast; so, as expected, the effect is still bigger in the interior. It is not surprising that the 
skilled wage falls by more than previously and, again, by more in the interior than in the coast: $9.03 \%$ and $6.17 \%$ respectively.

The production-cost effect, which was so important in the previous simulation, still works for the central government in the present case since we maintain the assumption that the central government varies its output of the consumption good to satisfy its budget constraint. The lower cost of production resulting from the lower skilled wage makes it possible to produce more $G C$ and in simulation 2 this effect is stronger than the previous case because of the larger drop in skilled wages. But the larger increase in $G C$ is more than offset by the smaller expansion of output by the regional governments who now hold GRH exogenous and allow $R$ to adjust to balance their budgets. The overall increase in $G H$ is still positive but much smaller than in simulation 1.

Prices and output. There are larger effects on prices as is expected, following the bigger fall in the skilled wage with $P_{F}$ falling by $2.7 \%$ and $P_{N}$ rising by $0.11 \%$. Output increases in each sector in each region by about two to three times the corresponding increases for simulation 1 . As in the previous cases, the output effect in the interior is greater than it is in coastal region, given the larger increases in private sector employment of skilled labour in the interior.

Income and consumption. As for simulation 1, income per household rises for unskilled households and falls for skilled households, with magnitudes being larger than in the previous case. These differences reflect different wage responses outlined above but also different profit effects: profit changes have the same signs as previously (positive for the informal sector and negative for the formal sector) but the magnitudes are bigger. The relative regional magnitudes are the same as before and this flows through into profit distribution to households - the formal-sector effects to the skilled households and the informal-sector 
effects to the unskilled households. On consumption, all effects are bigger in absolute value than in the previous case with one interesting exception: $C_{N S I}$ now rises by $0.34 \%$ compared to a fall of $0.03 \%$ in simulation 1 .

Welfare. The utility of all four household groups (two types, two regions) increase and do so by more than in the case of simulation 1, although only marginally for the skilled households in the coast. As in the previous case, the increase in welfare in the interior is greater than in the coast thus reducing the welfare disparity between the regions (although by less than in the case of simulation 1).

Regional disparities. Regional disparities in welfare are reduced in the short run, as they were in the previous simulation, although the narrowing is less pronounced. It is interesting that, in contrast to the previous case, disparities in per capita output and household income are also reduced in the short run so that in the present simulation the increase in the retirement age has beneficial short-run effects on all three measures of disparities. .

Long run. Since the short-run skilled wage falls by more in the interior than it does in the coast, long-run migration is from the interior to the coast, although it is partially offset by a reversal of the short-run migration of unskilled workers in the opposite direction. The migration leads to further welfare improvement for three of the four household groups, with the skilled households in the coast being the exception - there the migration of skilled households to the coast depresses incomes for the skilled to such an extent that welfare actually falls relative to the initial equilibrium. The same is true of consumption of informalsector output by the skilled households in the coast - the fall in income and the relative price change are large enough that consumption of the informal good actually falls relative to the 
initial equilibrium. The consequences for disparities is that all three measures (welfare, income and per capita output) of the inter-regional gap are reduced in the long run and that by more than in the short run.

In summary, compared to simulation 1, in the short run all four household groups are betteroff by a larger margin than they were in the previous simulation. In the long run this is reversed for the skilled households in the coast - the migration from the interior reduces incomes to such an extent that they are worse-off than they were in the initial equilibrium. Moreover, general effects on economic variables such as output are two to three times the magnitude in simulation 2 compared to simulation 1 . It seems that, on the whole, it is better to return the extra net revenue to the workers in terms of lower pension premia rather than to use it for the provision of extra government consumption goods.

An alternative closure for the regional government budgets is to assume that the extra revenue is returned to retirees in the form of a higher pension, rather than to employed skilled workers as lower pension premia. The effects of an increase in the retirement age are the same under this assumption as they are in the previous case (except, of course, for the effects on pensions and pension premia themselves). Thus it makes no difference to the national or regional economies whether the extra revenue is returned to retirees or to skilled workers. ${ }^{14}$

\footnotetext{
${ }^{14}$ Analytically, this can be seen by noting that the two terms $W_{R i}$ and $R_{i}$ appear only in equations (3) and (10) and in both of these equations can be written in the form: $r_{i} W_{R i}-\left(1-r_{i}\right) R_{i}$ which we may interpret as the net pension payments. It is only this composite term, not the individual components, which affects the rest of the economy.
} 


\section{Conclusions}

This paper has considered the regional economic effects of an increase in the retirement age in China within the context of a small theoretical model with some Chinese important characteristics. The model has two regions (coast and interior), two sectors (formal and informal), two types of labour (skilled and unskilled), two levels of government (central and regional) and captures some features of the Chinese tax-expenditure system. We assumed that skilled workers are employed only by the formal sector and that only skilled workers are covered by the pension scheme, reflecting the broad character of the pension system in China: low coverage of rural workers, unskilled workers in urban areas as well as skilled workers in the urban informal sector, with pension coverage concentrated amongst skilled government, SOE and corporate employees in the formal sector. In our model it was assumed that pensions are paid by regional governments since in practice the ultimate cost of pension are often underwritten by local and provincial governments. The resulting model was too difficult to solve analytically and we therefore linearised it and solved it numerically using parameter values derived from average Chinese data for the period 2008-2013.

We carried out two experiments, both of which involved shocks designed to mimic an increase in the retirement age from 60 to 61 . The experiments differed according to the assumption made about closure: in the first it was assumed that the regional governments used the extra net revenue resulting from the increase in the retirement age for the provision of a government- provided consumption good while in the second case it is assumed that the government used the revenue to reduce pension premia (or increase pension payments).

In the case where the regional governments spent the additional net revenue on increasing government output, we found that the increase in retirement age increases the supply of skilled workers and depresses the relative skilled wage in both regions but by more in the interior than in the coast. Output of each good increases in each region but formal- 
sector output increases by more (since only the formal sector uses skilled labour). With the change in the relative wage favouring unskilled labour, the income of skilled households falls but that of unskilled households rises. Welfare increases in both regions for both household types but by more for unskilled than skilled and by more in the interior than in the coast. In addition, the welfare disparity between the coast and the interior is reduced.

When we assumed that the regional governments use the additional net revenue to reduce pension premia or to increase pension payments, the results are generally substantially different. The increase in retirement age allows either a fall in pension premia of about $25 \%$ or a rise in pension payments of about $30-35 \%$. The rise in the skilled labour supply is the same as in the previous simulation but, because most of the extra labour now needs to be absorbed in the private sector (rather than in government production), the relative wage for skilled workers falls by more than in the first simulation. Flow-on effects to the rest of the economy are also generally greater, often two to three times as great. Welfare again rises for both household types in both regions, in all cases by more than in the previous case. The inter-regional welfare disparity is also reduced by this policy although by less than in the first simulation. It is interesting that disparities in output per capita and income also contract in this case in contrast to the first simulation where they increase in the short run but are reduced in the long run. Thus this policy has beneficial effects on the pension system (it allows the pension to be increased or pension premia to be reduced) and has beneficial effects on the rest of the economy, including output increases, welfare improvements and a reduction in all three measures of inter-regional disparities. Nevertheless, wages and incomes of the skilled fall while they rise for the unskilled. Thus, if households look to their incomes or wages (as they are assumed to do when they make migration decisions), skilled households may feel disadvantaged by the policy and resist increases in the retirement age while the 
unskilled will generally be in favour of increases in the retirement age for skilled workers (especially since, on the whole, they themselves do not retire at all).

References

Alonso, J., Caballero, M. A., Hui, L., Llanes, M. C., Tuesta, D., Hu, Y. and Cao, Y. (2011), "Potential Outcomes of Private Pension Developments in China", BBVA Working Papers Number 11/33.

Bao, S., Bodvarsson, O., Hou, J. and Zhao, Y. (2011), “The Regulation of Migration in A Transition economy: China's Hukou System”, Contemporary Economic Policy, 29(4): 564-579.

Barr, N. and Diamond, P. (2008), “China: The Pension System”, Chapter 14 in Barr, N. and Diamond, P., Reforming Pensions: Principles and Policy Choices, Oxford University Press, Oxford.

Barr, N. and Diamond, P. (2010), “Pension Reform in China: Issues, Options and Recommendations”. China Economic Research and Advisory Programme.

Cai, F. (2008), "Rethinking China's Pension Reform: The Relevance of International Experiences”, China Economist, 2008 Nov-Dec: 44-53.

Cai, Y. and Cheng, Y. (2014), "Pension Reform in China: Challenges and Opportunities”, Journal of Economic Surveys, 28(4): 636-651.

Chen, A. and Groenewold, N. (2013), "Does Investment Allocation Affect the Inter-Regional Output Gap in China?”, China Economic Review, 26: 197-206.

Chen, A. and Groenewold, N. (2014), "The Regional Economic Effects of a Reduction in Carbon Emission and an Evaluation of Offsetting Policies in China”, Papers in Regional Science, 93(2): 429-453.

Cheng, T. and Selden, M. (1994), “The Origins and Consequences of China's Hukou System”, The China Quarterly, 139: 644-668.

Dorfman, M. C., Holzmann, R., O'Keefe, P., Wang, D., Sin, Y. and Hinz, R.(2013), China's Pension System: A Vision, The World Bank, Washington, D.C.

Fleisher B., Li, H. and Zhao, M. (2010), "Human Capital, Economic Growth, and Regional Inequality in China”, Journal of Development Economics, 92: 215-231.

Giles, J.(2009), “Economic Restructuring and Retirement in Urban China”, Center for Retirement Research at Boston College, Hovey House, Working Paper 2008-24.

Giles, J., Wang, D. and Cai, W.(2011), “The Labor Supply and Retirement Behavior of China's Older Workers and Elderly in Comparative Perspective”, The World Bank, Policy Research Working Paper 5853.

He, C., Wei, Y. D. and Xie, X. (2008), 'Globalization, Institutional Change, and Industrial Location: Economic Transition and Industrial Concentration in China', Regional Studies, 42: 923-945. 
Herd, R., Hu, Y. and Koen, V. (2010), "Providing Greater Old-Age Security in China”, OECD Economics Department Working Papers. No.750.

Herrerías, M. J. and Monfort, J. O. (2015), “Testing Stochastic Convergence across Chinese Provinces, 1952-2008”, Regional Studies, 49(4): 485-501.

Jia, J., Guo, Q. and Zhang, J. (2014), "Fiscal Decentralization and Local Expenditure Policy in China”, China Economic Review, 28: 107-122.

Jin, H., Qian, Y. and Weingast, B. R. (2005), "Regional Decentralization and Fiscal Incentives: Federalism Chinese Style”, Journal of Public Economics, 89: 1719-1742.

Krugman, P. R. (1991),’Increasing Returns and Economic Geography”, Journal of Political Economy, 99: 483-99.

Li, H. and Merette, M. (2005), "Population Ageing and Pension System Reform in China: A Computable Overlapping-Generations General Equilibrium Model Analysis”, Journal of Chinese Economic and Business Studies, 3: 263-277.

Lin, P., Lin, C. and Ho, I. (2013), "Regional Convergence or Divergence in China? Evidence from Unit Root Tests with Breaks”, Annals of Regional Science, 50: 223-243.

Pissarides, C. A. and McMaster, I. (1990), "Regional Migration, Wages and Unemployment: Empirical Evidence and Implications for Policy”, Oxford Economic Papers, 42: 812831.

Rada, C.(2010), “Formal and Informal Sectors in China and India”, Economic Systems Research, 22(2):129-153.

Rizov, M. and Zhang, X. (2014), "Regional Disparities and Productivity in China: Evidence from Manufacturing Data”, Papers in Regional Science, 93(2): 321-339.

Shen, C., Jin, J. and Zou, H. (2012), "Fiscal Decentralization in China: History, Impacts, Challenges and Next Steps”, Annals of Economics and Finance, 13: 1-51.

Shen, C. and Zou, H. (2015), "Fiscal Decentralization and Public Services Provision in China”, Annals of Economics and Finance, 16: 53-78.

Song, S.(2009), "Pension Systems and Reforms in China and Russia”, The Chinese Economy, 42(3): 9-23.

Song, Z., Storesletten, K., Wang Y. and Zilibotti F. (2015), "Sharing High Growth across Generations: Pensions and Demographic Transition in China”, American Economic Journal: Macroeconomics, 7(2): 1-39.

Su, J. and Jefferson, G. H.(2012), "Differences in Returns to FDI between China's Coast and Interior: One Country, Two Economies?”, Journal of Asian Economics, 23: 259-269.

Tochkov, K. (2007), "Interregional Transfers and the Smoothing of Provincial Expenditure in China”, China Economic Review, 18: 54-65.

Wang, L., Beland, D. and Zhang, S. (2014a), "Pension Fairness in China”, China Economic Review, 28: 25-36.

Wang, L., Beland, D. and Zhang, S. (2014b), "Pension Financing in China: Is There a Looming Crises?”, China Economic Review, 30: 143-154.

Whalley, J. and Zhang, S. (2007), “A Numerical Simulation Analysis of (Hukou) Labour Mobility Restrictions in China”, Journal of Development Economics, 83: 392-410. 
Woodland, A.D. and Yoshida, C.(2006),“Risk Preference, Immigration Policy and Illegal Immigration”, Journal of Development Economics, 81: 500- 513.

Zeng, Y. (2011), "Effects of Demographic and Retirement-Age Policies on Future Pension Deficits, with an Application to China”, Population \& Development Review, 37(3): 553-569.

Zhang, W. (2007), “Further Reform of China’s Pension System: A Realistic Alternative Option to Fully Funded Individual Accounts”, Asian Economic Papers, 6: 112-135.

Zhang, X. (2006), "Fiscal Decentralization and Political Centralization in China: Implications for Growth and Inequality”, Journal of Comparative Economics, 34: 713-726.

Zhang, Z. and Martinez-Vazquez, J. (2003), “The System of Equalizing Transfers in China”, International Studies Program Working Paper 03-12, Andrew Young School of Policy Studies, Georgia State University.

Zheng, B.(2007), "The Origin of China's Partially Funded Social Security Scheme and Its Future Direction”, The Chinese Economy, 40(4): 6-28. 
Table 1 Data for main variables, China, 2008-2013 (average)

\begin{tabular}{|l|c|c|c|c|c|c|c|}
\hline Variable & $\mathrm{Y}_{\mathrm{N}}$ & $\mathrm{Y}_{\mathrm{F}}$ & $\begin{array}{c}\mathrm{L}_{\mathrm{NU}} \\
(10,000)\end{array}$ & $\begin{array}{c}\mathrm{L}_{\mathrm{FU}} \\
(10,000)\end{array}$ & $\begin{array}{c}\mathrm{L}_{\mathrm{FS}} \\
(10,000)\end{array}$ & $\begin{array}{c}\mathrm{L}_{\mathrm{S}} \\
(10,000)\end{array}$ & $\mathrm{W}_{\mathrm{S}}$ \\
\hline Interior & 33137.17 & 62413.27 & 24703.00 & 5484.43 & 6901.73 & 12398.30 & 2.23 \\
\hline Coast & 40638.33 & 97221.28 & 16469.34 & 7412.12 & 7603.00 & 11109.72 & 3.34 \\
\hline Variable & $\begin{array}{c}\mathrm{r} \\
(\%)\end{array}$ & $\mathrm{R}$ & $\mathrm{W}_{\mathrm{R}}$ & $\begin{array}{c}\mathrm{T}_{\mathrm{N}}=\mathrm{T}_{\mathrm{F}} \\
(\%)\end{array}$ & $\mathrm{GRH}$ & $\mathrm{GRF}_{\mathrm{F}}$ & $\mathrm{GRF}_{\mathrm{N}}$ \\
\hline Interior & 29.45 & 0.47 & 0.88 & 4.18 & 0.03 & 457.45 & 824.28 \\
\hline Coast & 23.68 & 0.39 & 0.99 & 4.18 & 0.04 & 464.45 & 668.99 \\
\hline Variable & $\mathrm{IIF}_{\mathrm{N}}$ & $\mathrm{IIF}$ & $\mathrm{IIH}$ & $\mathrm{IIH}$ & $\begin{array}{c}\mathrm{L}_{\mathrm{U}} \\
(10,000)\end{array}$ & $\begin{array}{c}\mathrm{Q}_{\mathrm{U}} \\
(10,000)\end{array}$ & $\begin{array}{c}\mathrm{Q}_{\mathrm{S}} \\
(10,000)\end{array}$ \\
\hline Interior & 7049.78 & 38958.69 & 0.23 & 2.22 & 30187.44 & 30187.44 & 17574.28 \\
\hline Coast & 22471.21 & 60362.05 & 0.94 & 4.15 & 23881.45 & 23881.45 & 14556.47 \\
\hline Variable & $\mathrm{J}_{\mathrm{U}}$ & $\mathrm{J}_{\mathrm{S}}$ & $\mathrm{L}_{\mathrm{GRS}}$ & $\mathrm{L}_{\mathrm{GCS}}$ & $\begin{array}{c}\mathrm{T}_{\mathrm{V}} \\
(\%)\end{array}$ & $\mathrm{GC}$ & $\mathrm{GH}$ \\
\hline Interior & 1.23 & 3.71 & 2927.78 & 2568.79 & 4.88 & 0.05 & 0.09 \\
\hline Coast & 1.94 & 6.63 & 2528.47 & 978.26 & 4.88 & 0.03 & 0.06 \\
\hline Variable & $\mathrm{C}_{\mathrm{NU}}$ & $\mathrm{C}_{\mathrm{FU}}$ & $\mathrm{C}_{\mathrm{NS}}$ & $\mathrm{C}_{\mathrm{FS}}$ & $\mathrm{P}_{\mathrm{N}}=\mathrm{P}_{\mathrm{F}}$ & $\mathrm{P}_{\mathrm{GR}}=\mathrm{P}_{\mathrm{GC}}$ & $\theta$ \\
\hline Interior & 0.35 & 0.82 & 1.06 & 2.47 & 1.00 & 2.23 & 0.75 \\
\hline Coast & 0.55 & 1.29 & 2.15 & 4.16 & 1.00 & 3.34 & 0.75 \\
\hline
\end{tabular}

Source: China Statistical Year Book (SSB, various issues)

Notes: output, wage, pension premium, pension income and government expenditure are in terms of unskilled labour. 
Table 2 Simulation Results

\begin{tabular}{|c|c|c|c|c|}
\hline \multirow[t]{2}{*}{ Variables } & \multicolumn{2}{|c|}{$\begin{array}{c}\text { Simulation 1: } \\
\text { GRH endogenous }\end{array}$} & \multicolumn{2}{|c|}{$\begin{array}{l}\text { Simulation 2: } \\
R \text { endogenous }\end{array}$} \\
\hline & SR & LR & SR & LR \\
\hline$v_{U I}$ & 1.6703 & 1.6813 & 2.0765 & 2.2734 \\
\hline$v_{U C}$ & 1.0885 & 1.1051 & 2.1581 & 2.2908 \\
\hline$v_{S I}$ & 0.6336 & 0.7230 & 1.2869 & 2.0360 \\
\hline$v_{S C}$ & 0.3081 & 0.1817 & 0.3117 & -0.7978 \\
\hline$g h_{I}$ & 14.4707 & 14.3862 & 4.4131 & 4.3801 \\
\hline$g h_{C}$ & 10.7214 & 10.8745 & 2.9847 & 2.9624 \\
\hline$j_{U I}$ & 0.0210 & 0.0236 & 0.0371 & 0.0689 \\
\hline$j_{U C}$ & 0.0798 & 0.0762 & 0.2668 & 0.2223 \\
\hline$j_{S I}$ & -0.3985 & -0.3204 & -0.6549 & -0.0686 \\
\hline$j_{S C}$ & -0.4379 & -0.5817 & -1.4630 & -2.7539 \\
\hline$p_{N}$ & 0.0410 & 0.0424 & 0.1074 & 0.1237 \\
\hline$p_{F}$ & -0.9983 & -1.0212 & -2.7084 & -2.9759 \\
\hline$y_{N I}$ & 0.1438 & 0.1486 & 0.3765 & 0.4334 \\
\hline$y_{N C}$ & 0.0301 & 0.0311 & 0.0787 & 0.0907 \\
\hline$y_{F I}$ & 0.5733 & 0.5253 & 2.1144 & 1.5299 \\
\hline$y_{F C}$ & 0.5388 & 0.5882 & 1.1215 & 1.7130 \\
\hline$w_{S I}$ & -2.8086 & -2.7179 & -9.0371 & -7.9179 \\
\hline$w_{S C}$ & -2.5711 & -2.7179 & -6.1659 & -7.9179 \\
\hline$l_{F S I}$ & 2.3836 & 2.2220 & 8.4431 & 6.4719 \\
\hline$I_{F S C}$ & 2.1116 & 2.2848 & 4.5790 & 6.6550 \\
\hline$l_{G C S I}$ & 2.4940 & 2.4377 & 7.4230 & 6.8341 \\
\hline$l_{G C S C}$ & 2.3890 & 2.4573 & 7.0147 & 7.6250 \\
\hline$l_{\text {GRSI }}$ & 18.7113 & 18.5591 & 0.1024 & -0.1983 \\
\hline$I_{G R S C}$ & 9.0845 & 9.2666 & -0.1248 & 0.2418 \\
\hline$l_{S I}$ & 6.2621 & 6.1246 & 6.2621 & 4.9718 \\
\hline$I_{S C}$ & 3.7230 & 3.8890 & 3.7230 & 5.2808 \\
\hline Output disparities & 0.0154 & -0.0457 & -0.4357 & -0.8671 \\
\hline Income disparities & 0.0239 & -0.0439 & -0.3127 & -0.8359 \\
\hline Welfare disparities & -0.5632 & -0.6539 & -0.2095 & -1.1194 \\
\hline
\end{tabular}

Notes: lower-case letters represent the proportional changes (log differential) of their upper-case counterparts. Output disparities equals $\left(y_{C}-l_{C}\right)-\left(y_{I}-l_{I}\right)$, income disparities equals $j_{C}-j_{I}$ and welfare disparities equals $v_{C^{-}} v_{I}$. "SR" and "LR" are abbreviations of "short run" and "long run". The shock is set to -0.1170 for $r_{I}$ and -0.1481 to $r_{C}$. 


\section{Appendix 1: Definition of variables}

$C_{F k i}=$ real private consumption of the formal-sector good per household of type $k$, region $i$,

$C_{N k i}=$ real private consumption of the informal-sector good per household of type $k$, region $i$,

$D_{j i}=$ productivity parameter, sector $j$, region $i$,

$G C_{i}=$ real central government-provided consumption good per household, region $i$,

$G H_{i}=$ real government-provided consumption per household, region $i$,

$G R F_{j i}=$ real regional government-provided public infrastructure, sector $j$, region $i$,

$G R H_{i}=$ real regional government-provided consumption good per household, region $i$,

$J=$ national income per household,

$J_{i}=$ real income per household, region $i$,

$J_{k i}=$ real income per household of type $k$, region $i$,

$L_{G C S i}=$ skilled labour hired by the central government in region $i$,

$L_{G R S i}=$ skilled labour hired by the regional government in region $i$

$L_{j k i}=$ employment, sector $j$, type $k$, region $i$.

$L_{k i}=$ employment, type $k$, region $i$,

$P_{F}=$ price of the formal-sector good in terms of unskilled labour,

$P_{G C i}=$ price of the central government-provided consumption good in terms of unskilled

labour, region $i$,

$P_{G R i}=$ price of the regional government-provided good in terms of unskilled labour, region $i$,

$P_{N}=$ price of the informal-sector good in terms of unskilled labour,

$Q=$ national population,

$Q_{i}=$ population, region $i$,

$Q_{k}=$ population, type $k$,

$Q_{k i}=$ population, type $k$, region $i$,

$r_{i}=$ proportion of skilled workers retired, region $i$,

$R_{i}=$ real pension premium per skilled worker, region $i$,

$T_{j i}=$ output tax rate, sector $j$, region $i$,

$T_{v}=$ value added tax rate,

$V=$ national utility,

$V_{i}=$ utility of the representative household, region $i$,

$V_{k i}=$ utility of the representative household of type $k$, region $i$,

$W_{R i}=$ real pension of retired skilled worker, region $i$,

$W_{S i}=$ real wage of skilled worker, region $i$,

$Y=$ national real output,

$Y_{i}=$ real output, region $i$,

$Y_{j i}=$ real output, sector $j$, region $i$,

$\theta=$ central government's share of valued-added tax,

$\Pi H_{k i}=$ real profit distribution per household of type $k$, region $i$,

$\Pi_{j i}=$ real profit, sector $j$, region $i$. 
Appendix 2 Linearised version of the model

The model of section 2 is linearised in terms of proportional differences by taking logarithms and differentials of each equation. The linearised form of equations (1) to (20) of the model are as follows, with the linearised form having the same number as the original equation but being distinguished by a prime.

The linearised utility function is:

(1') $\quad v_{k i}=\sigma_{V C N k i} c_{N k i}+\sigma_{V C F k i} C_{F k i}+\sigma_{V G H k i} g h_{i} \quad i=I, C ; k=U, S$

where lower-case letters represent the proportional changes (log differential) of their uppercase counterparts and

$$
\begin{aligned}
\sigma_{V C N k i} & =\frac{\gamma_{N k i} C_{N k i}^{-\rho_{k i}}}{\gamma_{N k i} C_{N k i}^{-\rho_{k i}}+\gamma_{F k i} C_{F k i}^{-\rho_{k i}}+\gamma_{G k i} G H_{i}^{-\rho_{k i}}}, \\
\sigma_{V C F k i} & =\frac{\gamma_{F k i} C_{F k i}^{-\rho_{k i}}}{\gamma_{N k i} C_{N k i}^{-\rho_{k i}}+\gamma_{F k i} C_{F k i}^{-\rho_{k i}}+\gamma_{G k i} G H_{i}^{-\rho_{k i}}}, \\
\sigma_{V G H k i} & =\frac{\gamma_{G k i} G H_{i}^{-\rho_{k i}}}{\gamma_{N k i} C_{N k i}^{-\rho_{k i}}+\gamma_{F k i} C_{F k i}^{-\rho_{k i}}+\gamma_{G k i} G H_{i}^{-\rho_{k i}}} .
\end{aligned}
$$

The demand function:

(2a') $c_{N k i}=j_{k i}-\sigma_{T V} t_{V}-p_{N}+\sigma_{C C N k i}\left(p_{N}-p_{F}\right) \quad i=I, C ; k=U, S$

where $\sigma_{C C N k i}=\frac{\frac{\rho_{k i}}{1+\rho_{k i}}\left(\frac{\gamma_{F k i}}{\gamma_{N k i}}\right)^{\frac{1}{1+\rho_{k i}}}\left(\frac{P_{N}}{P_{F}}\right)^{\frac{-\rho_{k i}}{1+\rho_{k i}}}}{1+\left(\frac{P_{N}}{P_{F}}\right)^{\frac{-\rho_{k i}}{1+\rho_{k i}}}\left(\frac{\gamma_{F k i}}{\gamma_{N k i}}\right)^{\frac{1}{1+\rho_{k i}}}}, \sigma_{T V}=\frac{T_{V}}{1-T_{V}}$.

(2b') $c_{F k i}=j_{k i}-\sigma_{T V} t_{V}-p_{F}+\sigma_{C C F k i}\left(p_{F}-p_{N}\right) \quad i=I, C ; k=U, S$

where $\sigma_{C C F k i}=\frac{\frac{\rho_{k i}}{1+\rho_{k i}}\left(\frac{\gamma_{N k i}}{\gamma_{F k i}}\right)^{\frac{1}{1+\rho_{k i}}}\left(\frac{P_{F}}{P_{N}}\right)^{\frac{-\rho_{k i}}{1+\rho_{k i}}}}{1+\left(\frac{P_{F}}{P_{N}}\right)^{\frac{-\rho_{k i}}{1+\rho_{k i}}}\left(\frac{\gamma_{N k i}}{\gamma_{F k i}}\right)^{\frac{1}{1+\rho_{k i}}}}$.

The definitions of real household income are:

(3a') $j_{U i}=\sigma_{J P U i} \pi h_{U i} \quad i=I, C$

where $\sigma_{J P U i}=\frac{\Pi H_{U i}}{J_{U i}}$.

(3b') $j_{S i}=\sigma_{J W R i}\left(\sigma_{W R W i} w_{S i}-\sigma_{W R R i} \hat{r}_{i}-\sigma_{r i} r_{i}^{*}\right)+\sigma_{J W W i}\left(w_{R i}+r_{i}^{*}\right)+\sigma_{J P S i} \pi h_{S i} \quad i=I, C$

where $\sigma_{J W R i}=\frac{\left(1-r_{i}\right)\left(W_{S i}-R_{i}\right)}{J_{S i}}, \sigma_{J W W i}=\frac{r_{i} W_{R i}}{J_{S i}}, \sigma_{J P S i}=\frac{\Pi H_{S i}}{J_{S i}}$,

$\sigma_{W R W i}=\frac{W_{S i}}{W_{S i}-R_{i}}, \sigma_{W R R i}=\frac{R_{i}}{W_{S i}-R_{i}}, \sigma_{r i}=\frac{r_{i}}{1-r_{i}}, r^{*}=d r / r$.

The skilled labor migration eqation:

(4') $w_{S C}=w_{S I}+\sigma_{\mu} \mu^{*}$

where $\sigma_{\mu}=\frac{\mu}{1+\mu}, \mu^{*}=\frac{d \mu}{\mu}$.

The production function:

(5a') $y_{N i}=d_{N i}+\alpha_{N U i} l_{N U i}+\alpha_{N G i} g r f_{N i} \quad i=I, C$ 
(5b') $y_{F i}=d_{F i}+\alpha_{F S i} l_{F S i}+\alpha_{F U i} l_{F U i}+\alpha_{F G i} g r f_{F i} \quad i=I, C$

The profit function:

(6a') $\pi_{N i}=\sigma_{P N Y i}\left(y_{N i}+p_{N}-\sigma_{T N i} t_{N i}\right)-\sigma_{P N L i} l_{N U i} \quad i=I, C$

where $\sigma_{P N Y i}=\frac{\left(1-T_{N i}\right) Y_{N i} P_{N}}{\Pi_{N i}}, \sigma_{T N i}=\frac{T_{N i}}{1-T_{N i}}, \sigma_{P N L i}=\frac{L_{N U i}}{\Pi_{N i}}$.

(6b') $\pi_{F i}=\sigma_{P F Y i}\left(y_{F i}+p_{F}-\sigma_{T F i} t_{F i}\right)-\sigma_{P F L U i} l_{F U i}-\sigma_{P F L S i}\left(\mathrm{w}_{S i}+l_{F S i}\right) \quad i=I, C$

where $\sigma_{P F Y i}=\frac{\left(1-T_{F i}\right) Y_{F i} P_{F}}{\Pi_{F i}}, \sigma_{T F i}=\frac{T_{F i}}{1-T_{F i}}, \sigma_{P F L U i}=\frac{L_{F U i}}{\Pi_{F i}}, \sigma_{P F L S i}=\frac{W_{S i} L_{F S i}}{\Pi_{F i}}$.

The labour demand function:

(7a') $y_{F i}+p_{F}-\sigma_{T F i} t_{F i}=w_{S i}+l_{F S i} \quad i=I, C$

(7b') $y_{F i}+p_{F}-\sigma_{T F i} t_{F i}=l_{F U i} \quad i=I, C$

(7c') $y_{N i}+P_{N}-\sigma_{T N i} t_{N i}=l_{N U i} \quad i=I, C$

Central government production and budget constraint:

(8') $q_{i}+g c_{i}=l_{G C S i} \quad i=I, C$

(9') $\sigma_{G C I}\left(q_{I}+p_{G C I}+g c_{I}\right)+\sigma_{G C C}\left(q_{C}+p_{G C C}+g c_{C}\right)=\theta^{*}+t_{v}$ $+\sigma_{J S I}\left(q_{S I}+j_{S I}\right)+\sigma_{J U I}\left(q_{U I}+j_{U I}\right)+\sigma_{J S C}\left(q_{S C}+j_{S C}\right)+\sigma_{J U C}\left(q_{U C}+j_{U C}\right)$

where $\sigma_{G C I}=\frac{Q_{I} P_{G C I} G C_{I}}{Q_{I} P_{G C I} G C_{I}+Q_{C} P_{G C C} G C_{C}}, \sigma_{G C C}=\frac{Q_{C} P_{G C C} G C_{C}}{Q_{I} P_{G C I} G C_{I}+Q_{C} P_{G C C} G C_{C}}$,

$\sigma_{J S I}=\frac{Q_{S I} J_{S I}}{Q_{S I} J_{S I}+Q_{U I} J_{U I}+Q_{S C} J_{S C}+Q_{U C} J_{U C}}, \sigma_{J U I}=\frac{Q_{U I} J_{U I}}{Q_{S I} J_{S I}+Q_{U I} J_{U I}+Q_{S C} J_{S C}+Q_{U C} J_{U C}}$,

$\sigma_{J S C}=\frac{Q_{S C} J_{S C}}{Q_{S I} J_{S I}+Q_{U I} J_{U I}+Q_{S C} J_{S C}+Q_{U C} J_{U C}}, \sigma_{J U C}=\frac{Q_{U C} J_{U C}}{Q_{S I} J_{S I}+Q_{U I} J_{U I}+Q_{S C} J_{S C}+Q_{U C} J_{U C}}$,

$\theta^{*}=d \theta / \theta$.

The regional government budget constraint and production:

(10') $\sigma_{Q G R H i}\left(q_{i}+p_{G R i}+g r h_{i}\right)+\sigma_{G R F N i}\left(g r f_{N i}+p_{G R i}\right) \quad i=I, C$

$+\sigma_{G R F F i}\left(g r f_{F i}+p_{G R i}\right)+\sigma_{G R Q W i}\left(r_{i}^{*}+q_{S i}+w_{R i}\right)$

$=\sigma_{G R T J i}\left(-\sigma_{\theta} \theta^{*}+t_{v}+\sigma_{J Q S i}\left(q_{S i}+j_{S i}\right)+\sigma_{J Q U i}\left(q_{U i}+j_{U i}\right)\right)$

$+\sigma_{G R Y N i}\left(t_{N i}+p_{N}+y_{N i}\right)+\sigma_{G R Y F i}\left(t_{F i}+p_{F}+y_{F i}\right)+\sigma_{G R Q R i}\left(q_{S i}+\widehat{r}_{i}-\sigma_{r i} r_{i}^{*}\right)$

where $\sigma_{Q G R H i}=\frac{Q_{i} P_{G R i} G R H_{i}}{Q_{i} P_{G R i} G R H_{i}+P_{G R i} G R F_{N i}+P_{G R i} G R F_{F i}+r_{i} Q_{S i} W_{R i}}$,

$\sigma_{G R F N i}=\frac{P_{G R i} G R F_{N i}}{Q_{i} P_{G R i} G R H_{i}+P_{G R i} G R F_{N i}+P_{G R i} G R F_{F i}+r_{i} Q_{S i} W_{R i}}$,

$\sigma_{G R F F i}=\frac{P_{G R i} G R F_{F i}}{Q_{i} P_{G R i} G R H_{i}+P_{G R i} G R F_{N i}+P_{G R i} G R F_{F i}+r_{i} Q_{S i} W_{R i}}$,

$\sigma_{G R Q W i}=\frac{r_{i} Q_{S i} W_{R i}}{Q_{i} P_{G R i} G R H_{i}+P_{G R i} G R F_{N i}+P_{G R i} G R F_{F i}+r_{i} Q_{S i} W_{R i}}$,

$\sigma_{G R T J i}=\frac{(1-\theta) T_{V}\left(Q_{S i} J_{S i}+Q_{U i} J_{U i}\right)}{T_{N i} P_{N} Y_{N i}+T_{F i} P_{F} Y_{F i}+\left(1-r_{i}\right) Q_{S i} R_{i}+(1-\theta) T_{V}\left(Q_{S i} J_{S i}+Q_{U i} J_{U i}\right)}$,

$\sigma_{J Q S i}=\frac{Q_{S i} J_{S i}}{Q_{S i} J_{S i}+Q_{U i} J_{U i}}, \sigma_{J Q U i}=\frac{Q_{U i} J_{U i}}{Q_{S i} J_{S i}+Q_{U i} J_{U i}}$, 


$$
\begin{aligned}
& \sigma_{G R Y N i}=\frac{T_{N i} P_{N} Y_{N i}}{T_{N i} P_{N} Y_{N i}+T_{F i} P_{F} Y_{F i}+\left(1-r_{i}\right) Q_{S i} R_{i}+(1-\theta) T_{V}\left(Q_{S i} J_{S i}+Q_{U i} J_{U i}\right)}, \\
& \sigma_{G R Y F i}=\frac{T_{F i} P_{F} Y_{F i}}{T_{N i} P_{N} Y_{N i}+T_{F i} P_{F} Y_{F i}+\left(1-r_{i}\right) Q_{S i} R_{i}+(1-\theta) T_{V}\left(Q_{S i} J_{S i}+Q_{U i} J_{U i}\right)}, \\
& \sigma_{G R Q R i}=\frac{\left(1-r_{i}\right) Q_{S i} R_{i}}{T_{N i} P_{N} Y_{N i}+T_{F i} P_{F} Y_{F i}+\left(1-r_{i}\right) Q_{S i} R_{i}+(1-\theta) T_{V}\left(Q_{S i} J_{S i}+Q_{U i} J_{U i}\right)}, \\
& \sigma_{\theta}=\frac{\theta}{1-\theta} .
\end{aligned}
$$

(11') $\sigma_{L G R H i}\left(q_{i}+g r h_{i}\right)+\sigma_{L G N i} g r f_{N i}+\sigma_{L G F i} g r f_{F i}=l_{G R S i} \quad i=I, C$

where $\sigma_{L G R H i}=\frac{Q_{i} G R H_{i}}{L_{G R S i}}, \sigma_{L G N i}=\frac{G R F_{N i}}{L_{G R S i}}, \sigma_{L G F i}=\frac{G R F_{F i}}{L_{G R S i}}$.

The price of the government good

(12a') $p_{G C i}=w_{S i} \quad i=I, C$

(12b') $p_{G R i}=w_{S i} \quad i=I, C$

The definition of regional and national output

(13a') $y_{i}=\sigma_{Y P N i}\left(p_{N}+y_{N i}\right)+\sigma_{Y P F i}\left(p_{F}+y_{F i}\right) \quad i=I, C$

where $\sigma_{Y P N i}=\frac{P_{N} Y_{N i}}{P_{N} Y_{N i}+P_{F} Y_{F i}}, \sigma_{Y P F i}=\frac{P_{F} Y_{F i}}{P_{N} Y_{N i}+P_{F} Y_{F i}}$, and

(13b') $y=\sigma_{Y Y I} y_{I}+\sigma_{Y Y C} y_{C}$

where $\sigma_{Y Y I}=\frac{Y_{I}}{Y_{I}+Y_{C}}, \sigma_{Y Y C}=\frac{Y_{C}}{Y_{I}+Y_{C}}$.

The definition of regional and national income:

(14a') $j_{i}+q_{i}=\sigma_{J Q U i}\left(j_{U i}+q_{U i}\right)+\sigma_{J Q S i}\left(j_{S i}+q_{S i}\right) \quad i=I, C$

(14b') $j+q=\sigma_{J J I}\left(j_{I}+q_{I}\right)+\sigma_{J J C}\left(j_{C}+q_{C}\right)$

where $\sigma_{J J I}=\frac{Q_{I} J_{I}}{Q_{I} J_{I}+Q_{C} J_{C}}, \sigma_{J J C}=\frac{Q_{C} J_{C}}{Q_{I} J_{I}+Q_{C} J_{C}}$.

The definition of regional and national utility:

(15a') $v_{i}+q_{i}=\sigma_{V Q U i}\left(q_{U i}+v_{U i}\right)+\sigma_{V Q S i}\left(q_{S i}+v_{S i}\right) \quad i=I, C$

where $\sigma_{V Q U i}=\frac{Q_{U i} V_{U i}}{Q_{U i} V_{U i}+Q_{S i} V_{S i}}, \sigma_{V Q S i}=\frac{Q_{S i} V_{S i}}{Q_{U i} V_{U i}+Q_{S i} V_{S i}}$, and

(15b') $v+q=\sigma_{V V I}\left(v_{I}+q_{I}\right)+\sigma_{V V C}\left(v_{C}+q_{C}\right)$

where $\sigma_{V V I}=\frac{Q_{I} V_{I}}{Q_{I} V_{I}+Q_{C} V_{C}}, \sigma_{V V C}=\frac{Q_{C} V_{C}}{Q_{I} V_{I}+Q_{C} V_{C}}$.

The relationship between $G H$ and its components:

(16') $g h_{i}=\sigma_{G H G R H i} g r h_{i}+\sigma_{G H G C i} g c_{i} \quad i=I, C$

where $\sigma_{G H G R H i}=\frac{G R H_{i}}{G H_{i}}, \sigma_{G H G C i}=\frac{G C_{i}}{G H_{i}}$.

Product market clearing:

(17a') $\sigma_{Y Y N I} y_{N I}+\sigma_{Y Y N C} y_{N C}$

$$
=\sigma_{C N U I}\left(q_{U I}+c_{N U I}\right)+\sigma_{C N S I}\left(q_{S I}+c_{N S I}\right)+\sigma_{C N U C}\left(q_{U C}+c_{N U C}\right)+\sigma_{C N S C}\left(q_{S C}+c_{N S C}\right)
$$




$$
\begin{aligned}
& \text { where } \sigma_{Y Y N I}=\frac{Y_{N I}}{Y_{N I}+Y_{N C}}, \sigma_{Y Y N C}=\frac{Y_{N C}}{Y_{N I}+Y_{N C}} \text {, } \\
& \sigma_{C N U I}=\frac{Q_{U I} C_{N U I}}{Q_{U I} C_{N U I}+Q_{S I} C_{N S I}+Q_{U C} C_{N U C}+Q_{S C} C_{N S C}} \\
& \sigma_{C N S I}=\frac{Q_{S I} C_{N S I}}{Q_{U I} C_{N U I}+Q_{S I} C_{N S I}+Q_{U C} C_{N U C}+Q_{S C} C_{N S C}} \text {, } \\
& \sigma_{C N U C}=\frac{Q_{U C} C_{N U C}}{Q_{U I} C_{N U I}+Q_{S I} C_{N S I}+Q_{U C} C_{N U C}+Q_{S C} C_{N S C}}, \\
& \sigma_{C N S C}=\frac{Q_{S C} C_{N S C}}{Q_{U I} C_{N U I}+Q_{S I} C_{N S I}+Q_{U C} C_{N U C}+Q_{S C} C_{N S C}} \text {. } \\
& \text { (17b') } \sigma_{Y Y F I} y_{F I}+\sigma_{Y Y F C} y_{F C} \\
& =\sigma_{C F U I}\left(q_{U I}+c_{F U I}\right)+\sigma_{C F S I}\left(q_{S I}+c_{F S I}\right)+\sigma_{C F U C}\left(q_{U C}+c_{F U C}\right)+\sigma_{C F S C}\left(q_{S C}+c_{F S C}\right) \\
& \text { where } \sigma_{Y Y F I}=\frac{Y_{F I}}{Y_{F I}+Y_{F C F}}, \sigma_{Y Y F C}=\frac{Y_{F C}}{Y_{F I}+Y_{F C F}} \text {, } \\
& \sigma_{C F U I}=\frac{Q_{U I} C_{F U I}}{Q_{U I} C_{F U I}+Q_{S I} C_{F S I}+Q_{U C} C_{F U C}+Q_{S C} C_{F S C}} \text {, } \\
& \sigma_{C F S I}=\frac{Q_{S I} C_{F S I}}{Q_{U I} C_{F U I}+Q_{S I} C_{F S I}+Q_{U C} C_{F U C}+Q_{S C} C_{F S C}} \text {, } \\
& \sigma_{C F U C}=\frac{Q_{U C} C_{F U C}}{Q_{U I} C_{F U I}+Q_{S I} C_{F S I}+Q_{U C} C_{F U C}+Q_{S C} C_{F S C}}, \\
& \sigma_{C F S C}=\frac{Q_{S C} C_{F S C}}{Q_{U I} C_{F U I}+Q_{S I} C_{F S I}+Q_{U C} C_{F U C}+Q_{S C} C_{F S C}} .
\end{aligned}
$$

Labour market-cleaning:

$$
\begin{array}{ll}
\left(18 \mathrm{a} 1^{\prime}\right) & \sigma_{L N U I} l_{N U I}+\sigma_{L F U I} l_{F U I}=l_{U I} \\
\left(18 \mathrm{a} 2^{\prime}\right) & \sigma_{L N U C} l_{N U C}+\sigma_{L F U C} l_{F U C}=l_{U C}
\end{array}
$$$$
\text { where } \sigma_{L N U C}=\frac{L_{N U C}}{L_{N U C}+L_{F U C}} \text {, }
$$

$$
\begin{gathered}
\sigma_{L F U C}=\frac{L_{F U C}}{L_{N U C}+L_{F U C}}, \\
\sigma_{L N U I}=\frac{L_{N U I}}{L_{N U I}+L_{F U I}}, \\
\sigma_{L F U I}=\frac{L_{F U I}}{L_{N U I}+L_{F U I}} .
\end{gathered}
$$

(18b') $\sigma_{L F S i} l_{F S i}+\sigma_{L G C S i} l_{G C S i}+\sigma_{L G R S i} l_{G R S i}=l_{S i} \quad i=I, C$

where $\sigma_{L F S i}=\frac{L_{F S i}}{L_{F S i}+L_{G C S i}+L_{G R S i}}$,

$$
\begin{gathered}
\sigma_{L G C S i}=\frac{L_{G C S i}}{L_{F S i}+L_{G C S i}+L_{G R S i}}, \\
\sigma_{L G R S i}=\frac{L_{G R S i}}{L_{F S i}+L_{G C S i}+L_{G R S i}} .
\end{gathered}
$$

The labour supply and population definitions: 
(19a') $l_{U i}=q_{U i} \quad i=I, C$

(19b') $l_{S i}=q_{S i}-\sigma_{r i} r_{i}^{*} \quad i=I, C$

(19c') $q_{U}=\sigma_{\text {QUUI }} q_{U I}+\sigma_{\text {QUUC }} q_{U C}$

where $\sigma_{Q U U I}=\frac{Q_{U I}}{Q_{U I}+Q_{U C}}, \sigma_{Q U U C}=\frac{Q_{U C}}{Q_{U I}+Q_{U C}}$.

(19d') $q_{S}=\sigma_{\mathrm{QSSI}} q_{S I}+\sigma_{\mathrm{QSSC}} q_{S C}$

where $\sigma_{Q S S I}=\frac{Q_{S I}}{Q_{S I}+Q_{S C}}, \sigma_{Q S S C}=\frac{Q_{S C}}{Q_{S I}+Q_{S C}}$.

(19e1') $q_{I}=\sigma_{\text {QIUI }} q_{U I}+\sigma_{\text {QISI }} q_{S I}$

where $\sigma_{\text {QIUI }}=\frac{Q_{U I}}{Q_{U I}+Q_{S I}}, \sigma_{Q I S I}=\frac{Q_{S I}}{Q_{U I}+Q_{S I}}$.

(19e'’) $q_{C}=\sigma_{Q C U C} q_{U C}+\sigma_{Q C S C} q_{S C}$

where $\sigma_{Q C U C}=\frac{Q_{U C}}{Q_{U C}+Q_{S C}}, \sigma_{Q C S C}=\frac{Q_{S C}}{Q_{U C}+Q_{S C}}$.

(19f') $q=\sigma_{\mathrm{QQU}} q_{U}+\sigma_{\mathrm{QQS}} q_{S}$

where $\sigma_{Q Q U}=\frac{Q_{U}}{Q_{U}+Q_{S}}, \sigma_{Q Q S}=\frac{Q_{S}}{Q_{U}+Q_{S}}$.

Profit distribution function:

(20a') $\pi_{N i}=q_{U i}+\pi h_{U i} \quad i=I, C$

(20b') $\pi_{F i}=q_{S i}+\pi h_{S i} \quad i=I, C$ 


\section{Appendix 3: Calibrating the linearised model}

The linearised model contains a number of parameters which have to be evaluated before the model can be put to work to simulate the effects of various shocks. These parameters fall into two groups. The first are parameters which appear in model relationships; $\gamma_{j k i}, \gamma_{G k i}$,and $\rho_{\text {ki }}$ appear in the utility function (1) and $\alpha_{j G i}$ and $\alpha_{j k i}$ appear in the production function (5). The remainder, on the other hand, are linearisation parameters which are all shares of some sort.

The model parameters were evaluated as follows. For the parameters of the utility function we broadly followed the method set out in Mansur and Whalley (1984) in which the substitution elasticity $\sigma_{\mathrm{ki}}=1 /\left(1+\rho_{\mathrm{ki}}\right)$ is derived from the equation:

$$
\sigma_{k i}=\frac{\eta_{k i}-\gamma_{k i}^{\sigma_{k i}}}{1-\gamma_{k i}^{\sigma_{k i}}}
$$

where $\eta_{k i}$ is the (uncompensated) own-price elasticity, values for which were derived as averages from Table 4 in Mansur and Whalley, and $\gamma_{k i}^{\sigma_{k i}}$ can be derived from ratios of consumption expenditure and our assumption that $\gamma_{N k i}+\gamma_{F k i}+\gamma_{G k i}=1$.

The production function parameters were calibrated as follows. Normally we would use the firm's first-order condition for profit-maximisation, equation (7a), 7(b) and (7c) to write the parameters in terms of costs shares:

$$
\begin{aligned}
& \alpha_{F S i}=\frac{W_{S i} L_{F S i}}{P_{F} Y_{F i}\left(1-T_{F i}\right)}, \\
& \alpha_{F U i}=\frac{L_{F U i}}{P_{F} Y_{F i}\left(1-T_{F i}\right)}, \\
& \alpha_{N U i}=\frac{L_{N U i}}{P_{N} Y_{N i}\left(1-T_{N i}\right)},
\end{aligned}
$$

However, this is not strictly possible for the government infrastructure variable since it is not one of the firm's choice variables but is determined by the government and taken as parametric by the firms. If we assume, nevertheless, that the quantity of the infrastructure is chosen to maximise profits or that the government provides a profit-maximising amount, we can also write:

$$
\begin{aligned}
\alpha_{F G i} & =\frac{G R F_{F i}}{P_{F} Y_{F i}\left(1-T_{F i}\right)} \\
\alpha_{N G i} & =\frac{G R F_{N i}}{P_{N} Y_{N i}\left(1-T_{N i}\right)} .
\end{aligned}
$$

We make this assumption and use data for the wage bill, government infrastructure expenditure and manufacturing output net of tax to compute the parameters.

The linearisation parameters can be evaluated directly from their definitions, given values for $V_{k i}, C_{N k i}, C_{F k i}, G H_{i}, J_{k i}, P_{j}, \Pi H_{U i}, \Pi H_{S i}, W_{S i}, Y_{N i}, Y_{F i}, L_{N U i}, L_{F U i}, L_{F S i}, \Pi_{N i}, \Pi_{F i}, L_{U i}$, $Q_{U i}, L_{S i}, Q_{i}, L_{G C S i}, L_{G R S i}, P_{G C i}, P_{G R i}, G C_{i}, G R H_{i}, Y_{i}, Y, J, J, V_{i}, V, Q_{S}, Q, T_{V}, r_{i}, R_{i}, W_{R i}, D_{N i}, D_{F i}$, $T_{N i}, T_{F i}, \theta, Q_{S i}, Q_{U}, G R F_{N i}, G R F_{F i}$. We normalise $P_{j}$ at unity and set $\theta$ at 0.75 to reflect the current division of VAT revenue between the central and regional governments. We then use these assumed values and the data for $Y_{j i}, T_{j i}, L_{N U i}, L_{F U i}, L_{F S i}, L_{S i}, W_{S i}, r_{i}, R_{i}, W_{R i}, G C_{i}, G R H_{i}$, $G R F_{j i}$ together with the model definitions to calculate the value of all other variables. The use of the model definitions ensures that the parameter values used in the simulations are consistent with the model constraints.

We therefore need data for two regions, the interior and the coast, for the variables $Y_{j i}$, $T_{j i}, L_{N U i}, L_{F U i}, L_{F S i}, L_{S i}, W_{S i}, r_{i}, R_{i}, W_{R i}, G C_{i}, G R H_{i}, G R F_{j i}$. The data we use are based on those 
for the Chinese provinces which we have allocated to the two regions as follows. The coastal region consists of Beijing, Tianjin, Hebei, Guangdong, Hainan, Shandong, Fujian, Zhejiang, Jiangsu, Shanghai, Liaoning and Guangxi with the remaining provinces being allocated to the interior region. The interior therefore consist of: Shanxi, Inner Mongolia, Jilin, Heilongjiang, Anhui, Jiangxi, Henan, Hubei, Hunan, Sichuan, Chongqing, Guizhou, Yunnan, Shaanxi, Gansu, Qinghai, Ningxia, Tibet, Xinjiang.

For each region we use data averaged over the six-year period 2008-2013 to avoid cyclical influences on the share parameters. All the data come from China Statistics Year Book (SSB, various issues).

The effect of increasing the retirement age by one year depends not only on the values of the $r_{i}$ (the proportion of the skilled labour which is retired in region $i$ ) but also on the age structure of the retired population. In fact, it depends on the proportion of the skilled labour force which is at retirement age. For retirement age of 60, using $t$ as age (in years), we have:

$$
r_{i}=\sum_{t=60}^{\infty} L_{S i t} / \sum_{t=1}^{\infty} L_{\text {Sit }}
$$

Changing retirement age from 60 to 61 :

$$
\begin{aligned}
& \Delta r_{i}=L_{S i 60} / \sum_{t=1}^{\infty} L_{S i t}=\left(L_{S i 60} / \sum_{t=60}^{\infty} L_{S i t}\right) r_{i} \\
& \Delta r_{i} / r_{i}=\left(L_{S i 60} / \sum_{t=60}^{\infty} L_{S i t}\right)
\end{aligned}
$$

So we need the proportion of the retired population which is at retirement age. But we don't have data by region on $L_{S i t}$ for each $i$ and $t$. However, if we assume linear decline in distribution of population by age after 60 , the size of the skilled labour force which is over aged 60 is given by $(1 / 2)\left(L_{E i}-60\right) L_{s i 60}$, where $L_{E i}$ is life expectancy. So the proportional change in $r_{i}$ is $2 /\left(L_{E i}-60\right)$. We can get this from the diagram below as well.

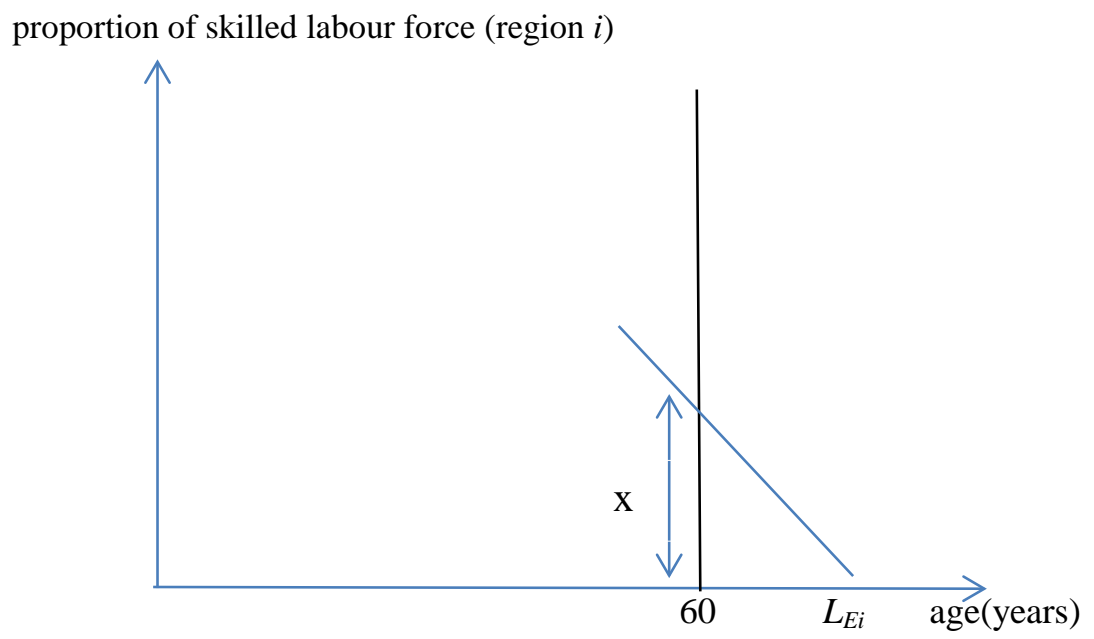

The right-hand part of the age distribution of the population of skilled workers is drawn in the diagram. So $\mathrm{x}$ is the proportion of the skilled labour force aged 60 (assuming a discrete distribution). The implication for the proportional change in $r_{i}$ is that it is $2 /\left(L_{E i}-\right.$ 60). This follows from the fact that the proportional change in $r_{i}$ at age 60 is simply $x$ divided by the area of the triangle which is $x$ divided by [(1/2) $\left.x\left(L_{E}-60\right)\right]$ which is $2 /\left(L_{E}-60\right)$. This is consistent with the results from the formula above. So, the proportional change in the retirement ratio for a one-year delay of retirement is inversely proportional to life expectancy. 
The life expectancy of the Chinese provinces in China Statistical Year Book 2013 shows that the average of life expectancy in the coast is about 77.1 while in the interior about 73.5 so the appropriate shocks (the proportional change in $r_{i}$ ) is about 0.1170 for the coast and 0.1481 for the interior. 
Appendix 4: Full Simulation Results

\begin{tabular}{|c|c|c|c|c|}
\hline \multirow[t]{2}{*}{ Variables } & \multicolumn{2}{|c|}{$\begin{array}{c}\text { Simulation 1: } \\
\text { GRH endogenous }\end{array}$} & \multicolumn{2}{|c|}{$\begin{array}{l}\text { Simulation 2: } \\
R \text { endogenous }\end{array}$} \\
\hline & SR & $\mathrm{LR}$ & SR & LR \\
\hline$v_{U I}$ & 1.6703 & 1.6813 & 2.0765 & 2.2734 \\
\hline$v_{U C}$ & 1.0885 & 1.1051 & 2.1581 & 2.2908 \\
\hline$v_{S I}$ & 0.6336 & 0.7230 & 1.2869 & 2.0360 \\
\hline$V_{S C}$ & 0.3081 & 0.1817 & 0.3117 & -0.7978 \\
\hline$c_{N U I}$ & 0.3874 & 0.3982 & 1.0334 & 1.1603 \\
\hline$c_{N U C}$ & 0.4462 & 0.4508 & 1.2631 & 1.3136 \\
\hline$C_{F U I}$ & 0.8447 & 0.8662 & 2.2724 & 2.5241 \\
\hline$C_{F U C}$ & 0.9036 & 0.9188 & 2.5021 & 2.6775 \\
\hline$c_{\text {NSI }}$ & $\begin{array}{l}-0.0321 \\
\end{array}$ & 0.0542 & 0.3415 & 1.0228 \\
\hline$c_{N S C}$ & -0.0953 & -0.2315 & -0.5311 & -1.7335 \\
\hline$c_{F S I}$ & 0.4252 & 0.5221 & 1.5805 & 2.3866 \\
\hline$C_{F S C}$ & 0.3620 & 0.2365 & 0.7079 & -0.3697 \\
\hline$g h_{I}$ & 14.4707 & 14.3862 & 4.4131 & 4.3801 \\
\hline$g h_{C}$ & 10.7214 & 10.8745 & 2.9847 & 2.9624 \\
\hline$j_{U I}$ & 0.0210 & 0.0236 & 0.0371 & 0.0689 \\
\hline$j_{U C}$ & 0.0798 & 0.0762 & 0.2668 & 0.2223 \\
\hline$j_{S I}$ & -0.3985 & -0.3204 & -0.6549 & -0.0686 \\
\hline$j_{S C}$ & -0.4379 & -0.5817 & -1.4630 & -2.7539 \\
\hline$\pi h_{U I}$ & 0.1108 & 0.1248 & 0.1958 & 0.3639 \\
\hline$\pi h_{U C}$ & 0.1647 & 0.1572 & 0.5503 & 0.4585 \\
\hline$\pi h_{S I}$ & -0.4250 & -0.3584 & -0.5940 & -0.1557 \\
\hline$\pi h_{S C}$ & -0.4595 & -0.5991 & -1.5869 & -2.8208 \\
\hline$p_{N}$ & 0.0410 & 0.0424 & 0.1074 & 0.1237 \\
\hline$p_{F}$ & -0.9983 & -1.0212 & -2.7084 & -2.9759 \\
\hline$y_{N I}$ & 0.1438 & 0.1486 & 0.3765 & 0.4334 \\
\hline$y_{N C}$ & 0.0301 & 0.0311 & 0.0787 & 0.0907 \\
\hline$y_{F I}$ & 0.5733 & 0.5253 & 2.1144 & 1.5299 \\
\hline$y_{F C}$ & 0.5388 & 0.5882 & 1.1215 & 1.7130 \\
\hline$w_{S I}$ & -2.8086 & -2.7179 & -9.0371 & -7.9179 \\
\hline$w_{S C}$ & -2.5711 & -2.7179 & -6.1659 & -7.9179 \\
\hline$\pi_{N I}$ & 0.1848 & 0.1910 & 0.4839 & 0.5571 \\
\hline$\pi_{N C}$ & 0.0711 & 0.0735 & 0.1862 & 0.2143 \\
\hline$\pi_{F I}$ & -0.4250 & -0.4959 & -0.5940 & -1.4461 \\
\hline$\pi_{F C}$ & -0.4595 & -0.4331 & -1.5869 & -1.2630 \\
\hline$I_{F S I}$ & 2.3836 & 2.2220 & 8.4431 & 6.4719 \\
\hline$I_{F S C}$ & 2.1116 & 2.2848 & 4.5790 & 6.6550 \\
\hline$I_{G C S I}$ & 2.4940 & 2.4377 & 7.4230 & 6.8341 \\
\hline$l_{G C S C}$ & 2.3890 & 2.4573 & 7.0147 & 7.6250 \\
\hline$I_{\text {GRSI }}$ & 18.7113 & 18.5591 & 0.1024 & -0.1983 \\
\hline$I_{G R S C}$ & 9.0845 & 9.2666 & -0.1248 & 0.2418 \\
\hline
\end{tabular}


Appendix 4: Full Simulation Results (continued)

\begin{tabular}{|c|c|c|c|c|}
\hline \multirow[t]{2}{*}{ Variables } & \multicolumn{2}{|c|}{$\begin{array}{c}\text { Simulation 1: } \\
\text { GRH endogenous }\end{array}$} & \multicolumn{2}{|c|}{$\begin{array}{l}\text { Simulation 2: } \\
\text { R endogenous }\end{array}$} \\
\hline & SR & LR & SR & LR \\
\hline$I_{S I}$ & 6.2621 & 6.1246 & 6.2621 & 4.9718 \\
\hline$I_{S C}$ & 3.7230 & 3.8890 & 3.7230 & 5.2808 \\
\hline$l_{N U I}$ & 0.1848 & 0.1910 & 0.4839 & 0.5571 \\
\hline$l_{F U I}$ & -0.4250 & -0.4959 & -0.5940 & -1.4461 \\
\hline$I_{N U C}$ & 0.0711 & 0.0735 & 0.1862 & 0.2143 \\
\hline$I_{F U C}$ & -0.4595 & -0.4331 & -1.5869 & -1.2630 \\
\hline$I_{U I}$ & 0.0740 & 0.0662 & 0.2881 & 0.1932 \\
\hline$l_{U C}$ & -0.0936 & -0.0837 & -0.3641 & -0.2442 \\
\hline$q_{U I}$ & 0.0740 & 0.0662 & 0.2881 & 0.1932 \\
\hline$q_{U C}$ & -0.0936 & -0.0837 & -0.3641 & -0.2442 \\
\hline$q_{S I}$ & 0.0000 & -0.1375 & 0.0000 & -1.2903 \\
\hline$q_{S C}$ & 0.0000 & 0.1661 & 0.0000 & 1.5579 \\
\hline$q_{I}$ & 0.0468 & -0.0087 & 0.1821 & -0.3527 \\
\hline$q_{C}$ & $\begin{array}{l}-0.0581 \\
\end{array}$ & 0.0109 & -0.2262 & 0.4383 \\
\hline$p_{G C I}$ & -2.8086 & -2.7179 & -9.0371 & -7.9179 \\
\hline$p_{G C C}$ & -2.5711 & -2.7179 & -6.1659 & -7.9179 \\
\hline$p_{G R I}$ & -2.8086 & -2.7179 & -9.0371 & -7.9179 \\
\hline$p_{G R C}$ & -2.5711 & -2.7179 & -6.1659 & -7.9179 \\
\hline$g c_{I}$ & 2.4472 & 2.4465 & 7.2409 & 7.1868 \\
\hline$g c_{C}$ & 2.4472 & 2.4465 & 7.2409 & 7.1868 \\
\hline$g r h_{I}$ & 33.2344 & 33.0192 & 0.0000 & 0.0000 \\
\hline$g h_{C}$ & 16.5237 & 16.7847 & 0.0000 & 0.0000 \\
\hline$y_{I}$ & -0.2135 & -0.2577 & -0.2202 & -0.7514 \\
\hline$y_{C}$ & -0.3031 & -0.2837 & -1.0642 & -0.8275 \\
\hline$y$ & -0.2664 & -0.2731 & -0.7187 & -0.7963 \\
\hline$i_{I}$ & -0.2660 & -0.2502 & -0.4810 & -0.4174 \\
\hline$j_{C}$ & -0.2422 & -0.2941 & -0.7937 & -1.2534 \\
\hline$j$ & -0.2664 & -0.2731 & -0.7187 & -0.7963 \\
\hline$V_{I}$ & 1.5102 & 1.5604 & 2.0007 & 2.5291 \\
\hline$v_{C}$ & 0.9470 & 0.9065 & 1.7913 & 1.4097 \\
\hline$v$ & 1.3301 & 1.3362 & 1.9730 & 2.0649 \\
\hline$r{ }_{I}$ & -15.0000 & -15.0000 & -15.0000 & -15.0000 \\
\hline$r^{*}{ }_{C}$ & -12.0000 & -12.0000 & -12.0000 & -12.0000 \\
\hline$r_{I}$ & 0.0000 & 0.0000 & -27.7614 & -26.0985 \\
\hline$r_{C}$ & 0.0000 & 0.0000 & -23.5078 & -26.9218 \\
\hline
\end{tabular}

Notes: lower-case letters represent the proportional changes (log differential) of their upper-case counterparts. "SR" and "LR" are abbreviations of "short run" and "long run". The shock is set to 0.1170 for $r_{I}$ and -0.1481 to $r_{C}$. 
Editor, UWA Economics Discussion Papers:

Sam Hak Kan Tang

University of Western Australia

35 Sterling Hwy

Crawley WA 6009

Australia

Email: ecoadmin@biz.uwa.edu.au

The Economics Discussion Papers are available at:

1980 - 2002: http://ecompapers.biz.uwa.edu.au/paper/PDF\%20of\%20Discussion\%20Papers/

Since 2001: http://ideas.repec.org/s/uwa/wpaper1.html

Since 2004: http://www.business.uwa.edu.au/school/disciplines/economics

\begin{tabular}{|c|c|c|}
\hline \multicolumn{3}{|c|}{$\begin{array}{l}\text { ECONOMICS DISCUSSION PAPERS } \\
2013\end{array}$} \\
\hline $\begin{array}{l}\text { DP } \\
\text { NUMBER }\end{array}$ & AUTHORS & TITLE \\
\hline 13.01 & $\begin{array}{l}\text { Chen, M., Clements, K.W. and } \\
\text { Gao, G. }\end{array}$ & THREE FACTS ABOUT WORLD METAL PRICES \\
\hline 13.02 & Collins, J. and Richards, O. & $\begin{array}{l}\text { EVOLUTION, FERTILITY AND THE AGEING } \\
\text { POPULATION }\end{array}$ \\
\hline 13.03 & $\begin{array}{l}\text { Clements, K., Genberg, H., } \\
\text { Harberger, A., Lothian, J., } \\
\text { Mundell, R., Sonnenschein, H. and } \\
\text { Tolley, G. }\end{array}$ & LARRY SJAASTAD, 1934-2012 \\
\hline 13.04 & Robitaille, M.C. and Chatterjee, I. & MOTHERS-IN-LAW AND SON PREFERENCE IN INDIA \\
\hline 13.05 & Clements, K.W. and Izan, I.H.Y. & $\begin{array}{l}\text { REPORT ON THE } 25^{\mathrm{TH}} \text { PHD CONFERENCE IN } \\
\text { ECONOMICS AND BUSINESS }\end{array}$ \\
\hline 13.06 & Walker, A. and Tyers, R. & QUANTIFYING AUSTRALIA’S “THREE SPEED” BOOM \\
\hline 13.07 & Yu, F. and Wu, Y. & PATENT EXAMINATION AND DISGUISED PROTECTION \\
\hline 13.08 & Yu, F. and Wu, Y. & $\begin{array}{l}\text { PATENT CITATIONS AND KNOWLEDGE SPILLOVERS: } \\
\text { AN ANALYSIS OF CHINESE PATENTS REGISTER IN } \\
\text { THE US }\end{array}$ \\
\hline 13.09 & Chatterjee, I. and Saha, B. & BARGAINING DELEGATION IN MONOPOLY \\
\hline 13.10 & Cheong, T.S. and Wu, Y. & $\begin{array}{l}\text { GLOBALIZATION AND REGIONAL INEQUALITY IN } \\
\text { CHINA }\end{array}$ \\
\hline 13.11 & Cheong, T.S. and Wu, Y. & INEQUALITY AND CRIME RATES IN CHINA \\
\hline 13.12 & Robertson, P.E. and Ye, L. & ON THE EXISTENCE OF A MIDDLE INCOME TRAP \\
\hline 13.13 & Robertson, P.E. & THE GLOBAL IMPACT OF CHINA’S GROWTH \\
\hline 13.14 & $\begin{array}{l}\text { Hanaki, N., Jacquemet, N., } \\
\text { Luchini, S., and Zylbersztejn, A. }\end{array}$ & $\begin{array}{l}\text { BOUNDED RATIONALITY AND STRATEGIC } \\
\text { UNCERTAINTY IN A SIMPLE DOMINANCE SOLVABLE } \\
\text { GAME }\end{array}$ \\
\hline 13.15 & $\begin{array}{l}\text { Okatch, Z., Siddique, A. and } \\
\text { Rammohan, A. }\end{array}$ & $\begin{array}{l}\text { DETERMINANTS OF INCOME INEQUALITY IN } \\
\text { BOTSWANA }\end{array}$ \\
\hline
\end{tabular}




\begin{tabular}{|c|c|c|}
\hline 13.16 & Clements, K.W. and Gao, G. & $\begin{array}{l}\text { A MULTI-MARKET APPROACH TO MEASURING THE } \\
\text { CYCLE }\end{array}$ \\
\hline 13.17 & Chatterjee, I. and Ray, R. & $\begin{array}{l}\text { THE ROLE OF INSTITUTIONS IN THE INCIDENCE OF } \\
\text { CRIME AND CORRUPTION }\end{array}$ \\
\hline 13.18 & Fu, D. and Wu, Y. & $\begin{array}{l}\text { EXPORT SURVIVAL PATTERN AND DETERMINANTS } \\
\text { OF CHINESE MANUFACTURING FIRMS }\end{array}$ \\
\hline 13.19 & Shi, X., Wu, Y. and Zhao, D. & $\begin{array}{l}\text { KNOWLEDGE INTENSIVE BUSINESS SERVICES AND } \\
\text { THEIR IMPACT ON INNOVATION IN CHINA }\end{array}$ \\
\hline 13.20 & $\begin{array}{l}\text { Tyers, R., Zhang, Y. and } \\
\text { Cheong, T.S. }\end{array}$ & $\begin{array}{l}\text { CHINA'S SAVING AND GLOBAL ECONOMIC } \\
\text { PERFORMANCE }\end{array}$ \\
\hline 13.21 & Collins, J., Baer, B. and Weber, E.J. & $\begin{array}{l}\text { POPULATION, TECHNOLOGICAL PROGRESS AND THE } \\
\text { EVOLUTION OF INNOVATIVE POTENTIAL }\end{array}$ \\
\hline 13.22 & Hartley, P.R. & THE FUTURE OF LONG-TERM LNG CONTRACTS \\
\hline 13.23 & Tyers, R. & $\begin{array}{l}\text { A SIMPLE MODEL TO STUDY GLOBAL } \\
\text { MACROECONOMIC INTERDEPENDENCE }\end{array}$ \\
\hline 13.24 & McLure, M. & $\begin{array}{l}\text { REFLECTIONS ON THE QUANTITY THEORY: PIGOU IN } \\
1917 \text { AND PARETO IN 1920-21 }\end{array}$ \\
\hline 13.25 & Chen, A. and Groenewold, N. & $\begin{array}{l}\text { REGIONAL EFFECTS OF AN EMISSIONS-REDUCTION } \\
\text { POLICY IN CHINA: THE IMPORTANCE OF THE } \\
\text { GOVERNMENT FINANCING METHOD }\end{array}$ \\
\hline 13.26 & Siddique, M.A.B. & $\begin{array}{l}\text { TRADE RELATIONS BETWEEN AUSTRALIA AND } \\
\text { THAILAND: } 1990 \text { TO } 2011\end{array}$ \\
\hline 13.27 & Li, B. and Zhang, J. & $\begin{array}{l}\text { GOVERNMENT DEBT IN AN INTERGENERATIONAL } \\
\text { MODEL OF ECONOMIC GROWTH, ENDOGENOUS } \\
\text { FERTILITY, AND ELASTIC LABOR WITH AN } \\
\text { APPLICATION TO JAPAN }\end{array}$ \\
\hline 13.28 & Robitaille, M. and Chatterjee, I. & $\begin{array}{l}\text { SEX-SELECTIVE ABORTIONS AND INFANT } \\
\text { MORTALITY IN INDIA: THE ROLE OF PARENTS' } \\
\text { STATED SON PREFERENCE }\end{array}$ \\
\hline 13.29 & Ezzati, P. & $\begin{array}{l}\text { ANALYSIS OF VOLATILITY SPILLOVER EFFECTS: } \\
\text { TWO-STAGE PROCEDURE BASED ON A MODIFIED } \\
\text { GARCH-M }\end{array}$ \\
\hline 13.30 & Robertson, P. E. & $\begin{array}{l}\text { DOES A FREE MARKET ECONOMY MAKE AUSTRALIA } \\
\text { MORE OR LESS SECURE IN A GLOBALISED WORLD? }\end{array}$ \\
\hline 13.31 & $\begin{array}{l}\text { Das, S., Ghate, C. and } \\
\text { Robertson, P. E. }\end{array}$ & $\begin{array}{l}\text { REMOTENESS AND UNBALANCED GROWTH: } \\
\text { UNDERSTANDING DIVERGENCE ACROSS INDIAN } \\
\text { DISTRICTS }\end{array}$ \\
\hline 13.32 & Robertson, P.E. and Sin, A. & $\begin{array}{l}\text { MEASURING HARD POWER: CHINA’S ECONOMIC } \\
\text { GROWTH AND MILITARY CAPACITY }\end{array}$ \\
\hline 13.33 & Wu, Y. & $\begin{array}{l}\text { TRENDS AND PROSPECTS FOR THE RENEWABLE } \\
\text { ENERGY SECTOR IN THE EAS REGION }\end{array}$ \\
\hline 13.34 & $\begin{array}{l}\text { Yang, S., Zhao, D., Wu, Y. and } \\
\text { Fan, J. }\end{array}$ & $\begin{array}{l}\text { REGIONAL VARIATION IN CARBON EMISSION AND } \\
\text { ITS DRIVING FORCES IN CHINA: AN INDEX } \\
\text { DECOMPOSITION ANALYSIS }\end{array}$ \\
\hline
\end{tabular}


2014

\begin{tabular}{|c|c|c|}
\hline $\begin{array}{l}\text { DP } \\
\text { NUMBER }\end{array}$ & AUTHORS & TITLE \\
\hline 14.01 & $\begin{array}{l}\text { Boediono, Vice President of the Republic } \\
\text { of Indonesia }\end{array}$ & $\begin{array}{l}\text { THE CHALLENGES OF POLICY MAKING IN A } \\
\text { YOUNG DEMOCRACY: THE CASE OF INDONESIA } \\
\text { (52ND SHANN MEMORIAL LECTURE, 2013) }\end{array}$ \\
\hline 14.02 & Metaxas, P.E. and Weber, E.J. & $\begin{array}{l}\text { AN AUSTRALIAN CONTRIBUTION TO } \\
\text { INTERNATIONAL TRADE THEORY: THE } \\
\text { DEPENDENT ECONOMY MODEL }\end{array}$ \\
\hline 14.03 & Fan, J., Zhao, D., Wu, Y. and Wei, J. & $\begin{array}{l}\text { CARBON PRICING AND ELECTRICITY MARKET } \\
\text { REFORMS IN CHINA }\end{array}$ \\
\hline 14.04 & McLure, M. & $\begin{array}{l}\text { A.C. PIGOU’S MEMBERSHIP OF THE } \\
\text { 'CHAMBERLAIN-BRADBURY’ COMMITTEE. } \\
\text { PART I: THE HISTORICAL CONTEXT }\end{array}$ \\
\hline 14.05 & McLure, M. & $\begin{array}{l}\text { A.C. PIGOU’S MEMBERSHIP OF THE } \\
\text { 'CHAMBERLAIN-BRADBURY’ COMMITTEE. } \\
\text { PART II: 'TRANSITIONAL’AND ‘ONGOING’ ISSUES }\end{array}$ \\
\hline 14.06 & King, J.E. and McLure, M. & HISTORY OF THE CONCEPT OF VALUE \\
\hline 14.07 & Williams, A. & $\begin{array}{l}\text { A GLOBAL INDEX OF INFORMATION AND } \\
\text { POLITICAL TRANSPARENCY }\end{array}$ \\
\hline 14.08 & Knight, K. & $\begin{array}{l}\text { A.C. PIGOU'S THE THEORY OF UNEMPLOYMENT } \\
\text { AND ITS CORRIGENDA: THE LETTERS OF } \\
\text { MAURICE ALLEN, ARTHUR L. BOWLEY, RICHARD } \\
\text { KAHN AND DENNIS ROBERTSON }\end{array}$ \\
\hline 14.09 & Cheong, T.S. and Wu, Y. & $\begin{array}{l}\text { THE IMPACTS OF STRUCTURAL RANSFORMATION } \\
\text { AND INDUSTRIAL UPGRADING ON REGIONAL } \\
\text { INEQUALITY IN CHINA }\end{array}$ \\
\hline 14.10 & $\begin{array}{l}\text { Chowdhury, M.H., Dewan, M.N.A., } \\
\text { Quaddus, M., Naude, M. and } \\
\text { Siddique, A. }\end{array}$ & $\begin{array}{l}\text { GENDER EQUALITY AND SUSTAINABLE } \\
\text { DEVELOPMENT WITH A FOCUS ON THE COASTAL } \\
\text { FISHING COMMUNITY OF BANGLADESH }\end{array}$ \\
\hline 14.11 & Bon, J. & $\begin{array}{l}\text { UWA DISCUSSION PAPERS IN ECONOMICS: THE } \\
\text { FIRST } 750\end{array}$ \\
\hline 14.12 & Finlay, K. and Magnusson, L.M. & $\begin{array}{l}\text { BOOTSTRAP METHODS FOR INFERENCE WITH } \\
\text { CLUSTER-SAMPLE IV MODELS }\end{array}$ \\
\hline 14.13 & Chen, A. and Groenewold, N. & $\begin{array}{l}\text { THE EFFECTS OF MACROECONOMIC SHOCKS ON } \\
\text { THE DISTRIBUTION OF PROVINCIAL OUTPUT IN } \\
\text { CHINA: ESTIMATES FROM A RESTRICTED VAR } \\
\text { MODEL }\end{array}$ \\
\hline 14.14 & Hartley, P.R. and Medlock III, K.B. & $\begin{array}{l}\text { THE VALLEY OF DEATH FOR NEW ENERGY } \\
\text { TECHNOLOGIES }\end{array}$ \\
\hline 14.15 & $\begin{array}{l}\text { Hartley, P.R., Medlock III, K.B., } \\
\text { Temzelides, T. and Zhang, X. }\end{array}$ & $\begin{array}{l}\text { LOCAL EMPLOYMENT IMPACT FROM COMPETING } \\
\text { ENERGY SOURCES: SHALE GAS VERSUS WIND } \\
\text { GENERATION IN TEXAS }\end{array}$ \\
\hline 14.16 & Tyers, R. and Zhang, Y. & $\begin{array}{l}\text { SHORT RUN EFFECTS OF THE ECONOMIC REFORM } \\
\text { AGENDA }\end{array}$ \\
\hline 14.17 & Clements, K.W., Si, J. and Simpson, T. & UNDERSTANDING NEW RESOURCE PROJECTS \\
\hline 14.18 & Tyers, R. & $\begin{array}{l}\text { SERVICE OLIGOPOLIES AND AUSTRALIA'S } \\
\text { ECONOMY-WIDE PERFORMANCE }\end{array}$ \\
\hline 14.19 & Tyers, R. and Zhang, Y. & $\begin{array}{l}\text { REAL EXCHANGE RATE DETERMINATION AND } \\
\text { THE CHINA PUZZLE }\end{array}$ \\
\hline
\end{tabular}




\begin{tabular}{|c|c|c|}
\hline \multicolumn{3}{|c|}{$\begin{array}{l}\text { ECONOMICS DISCUSSION PAPERS } \\
2014\end{array}$} \\
\hline $\begin{array}{l}\text { DP } \\
\text { NUMBER }\end{array}$ & AUTHORS & TITLE \\
\hline 14.20 & Ingram, S.R. & $\begin{array}{l}\text { COMMODITY PRICE CHANGES ARE } \\
\text { CONCENTRATED AT THE END OF THE CYCLE }\end{array}$ \\
\hline 14.21 & Cheong, T.S. and Wu, Y. & $\begin{array}{l}\text { CHINA'S INDUSTRIAL OUTPUT: A COUNTY-LEVEL } \\
\text { STUDY USING A NEW FRAMEWORK OF } \\
\text { DISTRIBUTION DYNAMICS ANALYSIS }\end{array}$ \\
\hline 14.22 & $\begin{array}{l}\text { Siddique, M.A.B., Wibowo, H. and } \\
\text { Wu, Y. }\end{array}$ & $\begin{array}{l}\text { FISCAL DECENTRALISATION AND INEQUALITY IN } \\
\text { INDONESIA: 1999-2008 }\end{array}$ \\
\hline 14.23 & Tyers, R. & $\begin{array}{l}\text { ASYMMETRY IN BOOM-BUST SHOCKS: } \\
\text { AUSTRALIAN PERFORMANCE WITH OLIGOPOLY }\end{array}$ \\
\hline 14.24 & Arora, V., Tyers, R. and Zhang, Y. & $\begin{array}{l}\text { RECONSTRUCTING THE SAVINGS GLUT: THE } \\
\text { GLOBAL IMPLICATIONS OF ASIAN EXCESS } \\
\text { SAVING }\end{array}$ \\
\hline 14.25 & Tyers, R. & $\begin{array}{l}\text { INTERNATIONAL EFFECTS OF CHINA’S RISE AND } \\
\text { TRANSITION: NEOCLASSICAL AND KEYNESIAN } \\
\text { PERSPECTIVES }\end{array}$ \\
\hline 14.26 & Milton, S. and Siddique, M.A.B. & $\begin{array}{l}\text { TRADE CREATION AND DIVERSION UNDER THE } \\
\text { THAILAND-AUSTRALIA FREE TRADE } \\
\text { AGREEMENT (TAFTA) }\end{array}$ \\
\hline 14.27 & Clements, K.W. and Li, L. & VALUING RESOURCE INVESTMENTS \\
\hline 14.28 & Tyers, R. & $\begin{array}{l}\text { PESSIMISM SHOCKS IN A MODEL OF GLOBAL } \\
\text { MACROECONOMIC INTERDEPENDENCE }\end{array}$ \\
\hline 14.29 & Iqbal, K. and Siddique, M.A.B. & $\begin{array}{l}\text { THE IMPACT OF CLIMATE CHANGE ON } \\
\text { AGRICULTURAL PRODUCTIVITY: EVIDENCE } \\
\text { FROM PANEL DATA OF BANGLADESH }\end{array}$ \\
\hline 14.30 & Ezzati, P. & $\begin{array}{l}\text { MONETARY POLICY RESPONSES TO FOREIGN } \\
\text { FINANCIAL MARKET SHOCKS: APPLICATION OF A } \\
\text { MODIFIED OPEN-ECONOMY TAYLOR RULE }\end{array}$ \\
\hline 14.31 & Tang, S.H.K. and Leung, C.K.Y. & $\begin{array}{l}\text { THE DEEP HISTORICAL ROOTS OF } \\
\text { MACROECONOMIC VOLATILITY }\end{array}$ \\
\hline 14.32 & Arthmar, R. and McLure, M. & $\begin{array}{l}\text { PIGOU, DEL VECCHIO AND SRAFFA: THE } 1955 \\
\text { INTERNATIONAL ‘ANTONIO FELTRINELLI’ PRIZE } \\
\text { FOR THE ECONOMIC AND SOCIAL SCIENCES }\end{array}$ \\
\hline 14.33 & McLure, M. & $\begin{array}{l}\text { A-HISTORIAL ECONOMIC DYNAMICS: A BOOK } \\
\text { REVIEW }\end{array}$ \\
\hline 14.34 & Clements, K.W. and Gao, G. & $\begin{array}{l}\text { THE ROTTERDAM DEMAND MODEL HALF A } \\
\text { CENTURY ON }\end{array}$ \\
\hline
\end{tabular}




\begin{tabular}{|c|c|c|}
\hline \multicolumn{3}{|c|}{$\begin{array}{l}\text { ECONOMICS DISCUSSION PAPERS } \\
2015\end{array}$} \\
\hline $\begin{array}{l}\text { DP } \\
\text { NUMBER }\end{array}$ & AUTHORS & TITLE \\
\hline 15.01 & Robertson, P.E. and Robitaille, M.C. & $\begin{array}{l}\text { THE GRAVITY OF RESOURCES AND THE } \\
\text { TYRANNY OF DISTANCE }\end{array}$ \\
\hline 15.02 & Tyers, R. & $\begin{array}{l}\text { FINANCIAL INTEGRATION AND CHINA'S GLOBAL } \\
\text { IMPACT }\end{array}$ \\
\hline 15.03 & Clements, K.W. and Si, J. & $\begin{array}{l}\text { MORE ON THE PRICE-RESPONSIVENESS OF FOOD } \\
\text { CONSUMPTION }\end{array}$ \\
\hline 15.04 & Tang, S.H.K. & $\begin{array}{l}\text { PARENTS, MIGRANT DOMESTIC WORKERS, AND } \\
\text { CHILDREN'S SPEAKING OF A SECOND } \\
\text { LANGUAGE: EVIDENCE FROM HONG KONG }\end{array}$ \\
\hline 15.05 & Tyers, R. & $\begin{array}{l}\text { CHINA AND GLOBAL MACROECONOMIC } \\
\text { INTERDEPENDENCE }\end{array}$ \\
\hline 15.06 & $\begin{array}{l}\text { Fan, J., Wu, Y., Guo, X., Zhao, D. and } \\
\text { Marinova, D. }\end{array}$ & $\begin{array}{l}\text { REGIONAL DISPARITY OF EMBEDDED CARBON } \\
\text { FOOTPRINT AND ITS SOURCES IN CHINA: A } \\
\text { CONSUMPTION PERSPECTIVE }\end{array}$ \\
\hline 15.07 & $\begin{array}{l}\text { Fan, J., Wang, S., Wu, Y., Li, J. and } \\
\text { Zhao, D. }\end{array}$ & $\begin{array}{l}\text { BUFFER EFFECT AND PRICE EFFECT OF A } \\
\text { PERSONAL CARBON TRADING SCHEME }\end{array}$ \\
\hline 15.08 & Neill, K. & $\begin{array}{l}\text { WESTERN AUSTRALIA'S DOMESTIC GAS } \\
\text { RESERVATION POLICY THE ELEMENTAL } \\
\text { ECONOMICS }\end{array}$ \\
\hline 15.09 & Collins, J., Baer, B. and Weber, E.J. & $\begin{array}{l}\text { THE EVOLUTIONARY FOUNDATIONS OF } \\
\text { ECONOMICS }\end{array}$ \\
\hline 15.10 & $\begin{array}{l}\text { Siddique, A., Selvanathan, E. A. and } \\
\text { Selvanathan, S. }\end{array}$ & $\begin{array}{l}\text { THE IMPACT OF EXTERNAL DEBT ON ECONOMIC } \\
\text { GROWTH: EMPIRICAL EVIDENCE FROM HIGHLY } \\
\text { INDEBTED POOR COUNTRIES }\end{array}$ \\
\hline 15.11 & Wu, Y. & $\begin{array}{l}\text { LOCAL GOVERNMENT DEBT AND ECONOMIC } \\
\text { GROWTH IN CHINA }\end{array}$ \\
\hline 15.12 & Tyers, R. and Bain, I. & $\begin{array}{l}\text { THE GLOBAL ECONOMIC IMPLICATIONS OF } \\
\text { FREER SKILLED MIGRATION }\end{array}$ \\
\hline 15.13 & Chen, A. and Groenewold, N. & $\begin{array}{l}\text { AN INCREASE IN THE RETIREMENT AGE IN } \\
\text { CHINA: THE REGIONAL ECONOMIC EFFECTS }\end{array}$ \\
\hline
\end{tabular}

